\title{
A REVISION OF THE GENUS BOUGAINVILLIA (ANTHOMEDUSAE)
}

(Received May 1960)

\author{
M. Vannucci* \\ $\&$ \\ W. J. Rees**
}

CONTENTS

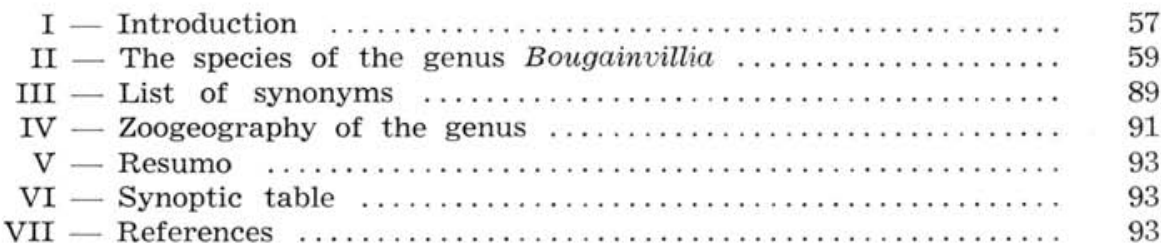

\section{I - INTRODUCTION}

The genus Bougainvillia is a well defined genus of the family Bougainviliidae of the Order Anthomedusae. The adult medusa is characterized by the presence of four dichotomously-branching oral tentacles and four marginal bulbs each bearing two or more tentacles all of the same kind. The hydroid stock is athecate, the hydranths have a conical proboscis and a single whorl of filiform tentacles; the medusa buds are borne below the hydranths, on their pedicels or on the stems and always produce Bougainvilliid medusae.

The type species is Bougainvillia macloviana, described in 1830 by Lesson under the name Cyanaea bougainvillii, later re-

* This paper was partly prepared while holding a UNESCO fellowship and with a grant in aid of the National Research Council of Brazil.

** British Museum (Natural History).

Publ. ne 126 do Inst. Ocean. da USP. 
described and renamed by himself as the type species of the genus. For the history and synonymy of the name Bougainvillia see Kramp (1926, p. 41).

The genus Bougainvillia is well defined and it is easy to recognize a medusa belonging to it, but the species are usually difficult to separate and many of them are of doubtful validity. In recent years Russell (1953, p. 143) reviewed the British species and Rees (1956a) revised the genus Perigonimus showing that several species previously referred to it really belong to the genus Bougainvillia. The same author (Rees, 1938) demonstrated that the type species of the genus Perigonimus is Bougainvillia muscoides M. Sars and thus the genus Perigonimus must be abandoned. The status of the remaining species of the genus Bougainvillia is now considered in an attempt to bring up to date our knowledge of this group.

The Bougainvillia-like hydroids are very difficult to determine because superficially similar hydroids produce quite different medusae, belonging to different families (Rees, 1956a). Therefore hydroids with a single whorl of filiform tentacles and a conical proboscis may belong to several different genera, according to whether they have fixed gonophores or according to the type of medusae they produce. Hydroids bearing no gonophores can seldom be adequately determined and when they bear medusa buds, these must be sufficiently developed to allow the recognition of the distinctive features of the medusa. Furthermore the valid hydroid species belonging to the genus Bougainvillia are very difficult to differentiate, not only because they differ only slightly from each other, but also because they are greatly influenced by environmental conditions (Hincks 1868, p. 109; Pictet, 1893; Hallez, 1905; Brink, 1925). Many of the "species" of hydroids described under the name Bougainvillia and whose life history is still unknown must be considered as doubtful species, until their medusae are segregated.

Material has been examined at the British Museum (Nat. Hist.) ; at the Zoological Museum of the University of Copenhagen, from the Museum of Comparative Zoology, Harvard University, as well as much living and preserved material from Brazil and in European waters.

\section{GENERIC CHARACTERS}

HYdRoId - A single whorl of filiform tentacles. Conical hypostome. Stem either simple or fascicled, branched or unbranched. Perisarc always present, it may be soft with foreign particles attached, or it may be hard and horny. It may extend up to the tentacle whorl forming what has been called a pseudo- 
hydrotheca. Medusa buds are borne single or in clusters and they may be sessile or on short pedicels; the buds are produced on branches or on stems, but always arise below the hydranths themselves.

Medusa - Four radial canals and ring canal; the former are straight and simple. Dichotomously-branching oral tentacles, each branch terminating in a nematocyst knob. The oral tentacles arise above the mouth opening, thus leaving mouth free. Marginal tentacles are all alike, grouped into four perradial clusters arising from a marginal bulb. Ocelli usually present on the adaxial surface, either on the base of the tentacles, or just below the tentacles on the bulb. A peduncle may be present. Gonads on stomach, either adradial or interradial, rarely perradial. Medusa buds may be produced asexually on the manubrium.

The nearest relative to Bougainvillia is Nemopsis with two different types of marginal tentacle. Every marginal bulb of Nemopsis bears a median pair of rather stiff tentacles with swollen club-shaped extremities, besides two or more simple tentacles. This genus includes only a few rare species.

Both genera belong to the sub-family Bougainvilliinae, family Bougainvilliidae (see Russell, 1953).

\section{ACKNOWLEDGEMENTS}

Special thanks are due to Dr. P. L. Kramp for identified specimens of $B$. niobe, B. fulva, B. platygaster and B. macloviana and also to $\mathrm{Mr}$. K. Petersen for specimens of B. superciliaris for comparative purposes. Specimens were examined both at the $\mathrm{Mu}$ seum of Copenhagen and in the British Museum. The Museum of Comparative Zoology of Harvard University, Mass. also lent material (by courtesy of Dr. E. Deichmann) of the following species: B. carolinensis (hydroid, M.C.Z. n. ${ }^{\circ} 43$ ), B. fulva (M.C.Z. n. ${ }^{\circ}$ 1316), B. niobe (M.C.Z. n..$^{\circ}$ 8003) and B. superciliaris (M.C.Z. n. ${ }^{\circ}$ 1425). Thanks are due also to Dr. R. E. Foerster who gave his last copy of his 1923 paper to one of the authors and donated specimens of $B$. multitentaculata to the British Museum (Nat. Hist.), specially for the present study.

\section{II - THE SPECIES OF THE GENUS BOUGAINVILLIA}

\section{Bougainvillia alderi (Hodge)}

Podocoryne alderi Hodge 1861, p. 82, pl. ii, figs. 10-15.

Corynopsis alderi Allman 1864, p. 353.

Bougainvillia alderi Hartlaub 1911, p. 182, fig. 161. 
Hodge was rather diffident about publishing his account of this hydroid and its newly liberated medusa; it seems probable that the hydroid and young medusa do not belong to the same species as the former appears to be a Podocoryne and the latter a young medusa of Bougainvillia ramosa.

\section{Bougainvillia (?) balei Stechow}

Bougainvillia (?) balei Stechow 1924, p. 58.

" $\quad$ Stechow 1925, p. 199, fig. B.

TYPe LOCALITY - Northeast of Heirisson Prong, Shark's Bay, West Australia. Only the hydroid is known. The specimens were collected by Michaelsen and Hartmeyer during their 1905 voyage to West and Southwest Australia.

HYDROID - Colony three to five $\mathrm{mm}$. high, little or not branched. Monosiphonic stem. Basal portion of the perisarc of the stem and of the pedicels wrinkled. Sand particles adherent on the periderm and basal portion of the hydranths. Hydranths fusiform with 15-17 tentacles; the apical hydranth is larger than the lateral ones. No gonophore or medusa buds were seen by Stechow.

Medusa - Unknown.

Distribution - West Australia (Shark's Bay).

Discussion - This must be considered an insufficiently-described species. The absence of gonophores in the type material, the only known samples, renders even the generic determination doubtful. Stechow $(1924$, p. 58), considers the difference in size between the apical and lateral hydranths as a suggestion that his material belongs to the genus Bougainvillia and not to Leuckartiara (=Perigonimus auct.) with which it might otherwise be confused. According to the same author (l.c., p. 59) it is very similar to $B$. vagans but smaller.

\section{Bougainvillia bitentaculata Uchida}

Bougainvillia bitentaculata Uchida 1925, p. 84, fig. 10.

TyPe LOCALITY - Yunohama (Northern Japan). A single specimen.

SPECIFIC CHARACTERS - The presence of a peduncle associated with the small size of the bell at maturity and the paucity of bulbar tentacles (2) ; there is a single ocellus per bulb, a character unique in the genus. 


\section{HYDROID - Unknown.}

MedusA - Bell $1 \mathrm{~mm}$ high and 0.8 wide, with a slight elevation at the apex. Judging from the figure, a peduncle is present, the stomach is about half as tall as the sub-umbrellar space. The oral tentacles have a short basal trunk and branch dichotomously only twice. The marginal bulbs are described as being triangular but in the figure they look more like spherical triangles and appear almost rounded; they bear two tentacles each. There is a single black ocellus located on the bulb between the bases of the two tentacles. There are four large interradial gonads. The manubrium and gonads are brownish, the ocellus black.

\section{Distribution - Yunohama, Northern Japan.}

Discussion - To our knowledge not recorded again since the original description of the single specimen collected. Its closest ally which is devoid of ocelli altogether and has no peduncle is $B$. frondosa (known from Florida to southern Brazil). It is rather similar to the dwarf varieties of $B$. ramosa, but the presence of a peduncle and the single ocellus make it readily distinguishable.

\section{Bougainvillia britannica (Forbes)}

A detailed synonymy may be found in Russell's Monograph (1953) ; only chief synonyms are listed below.

Hippocrene britannica Forbes 1841, p. 84, pl. 1, fig. 2a.

Bougainvillia britannica Lesson 1843, p. 291.

Forbes 1848 , p. 52 , pl. 12 , fig. 1.

" nigritella Forbes 1848 , p. 63 , pl. 12, fig. 2 .

Margelis ramosa L. Agassiz 1862, p. 344 (in part).

nigritella L. Agassiz 1862, p. 345.

Bougainvillia britannica Allman 1872, p. 313, pl. 9, fig. 8 .

Margelis ramosa Haeckel 1879, p. 88 (in part). zygonema Haeckel 1879, p. 635.

?Bougainvillia flavida Hartlaub 1897, p. 456, pl. 14, figs. 1-4, 7-10, not figs. 5-6.

Bougainvillia xantha Hartlaub 1897 , p. 461, pl. 15, figs. $2-3$; pl. 16, fig. 3 ; pl. $16 \mathrm{~b}$, fig. 19 .

" bella Hartlaub 1897, p. 470, pl. 15, fig. 7 ; pl. 16a, figs. 6-11.

Margelis bella Browne 1900, p. 708.

Bougainvillia britannica Mayer 1910, p. 161, pl. 17, fig. 8 (in part). xantha Mayer 1910, p. 165.

?Bougainvillia simplex Hartlaub 1911, p. 181, fig. 160 .

?Bougainvillia charcoti Le Danois 1913, p. 15, figs. 1-3.

Bougainvillia britannica Kramp 1927, p. 58.

" " Perrier 1936, p. 44.

" $\quad$ Kramp 1937, p. 47, fig. $15 \mathrm{~b}$.

" $\quad$ Russell 1938, p. 421 .

" $\quad$ Russell 1953, p. 158, pl. 8, figs. 2-3; pl. 9, figs. 1-3.

" $\quad$ Kramp 1959, p. 109, fig. 90. 
Type Locality - Probably the Kyles of Bute, Clyde Sea Area.

MATERIAL SEeN - Abundant material seen both alive and preserved.

SPECIFic Characters - Jelly very thick. No peduncle. Oral tentacles branching four to six times. Usually twelve to seventeen, but sometimes up to 30 , tentacles on each marginal bulb. Ocelli elongated in shape, situated on bases of marginal tentacles.

HYDROID - The hydroid is perhaps the species described as B. flavida by Hartlaub in 1897 (p. 456, l.c.) ; Kramp (1927, p. 58) regards this as certain, but Russell was uncertain. Later Rees (1956a) identified Perigonimus linearis Alder 1862 as a Bougainvillia from a re-examination of Alder's original drawings; both hydroids may belong to $B$. britannica. Colonies five to seven $\mathrm{mm}$ high, monosiphonic, simple or slightly branched. Perisarc slightly wrinkled, dilated into membraneous cups around the basal portion of the hydranths and extending up to the tentacles. Proboscis short. Eight to ten filiform tentacles. Medusa buds borne singly or in clusters on branching stalks immediately below the hydranths. Colonies orange coloured.

AdULt MEDUSA - Umbrella usually six to seven $\mathrm{mm}$. may be eight $\mathrm{mm}$. high. The jelly is thick, the bell globular. No peduncle, large cruciform stomach. The oral tentacles have a long basal trunk and branch dichotomously from four to six times. Nematocyst clusters at the end of the oral tentacles. Radial canals broad, ring canal narrow. Peduncle absent. Adradial gonads, sometimes spreading over interradial portion of manubrium. Marginal bulbs are broadly triangular, about half as wide as the interradial space. There are usually $12-17$ but there may be as many as 30 tentacles per marginal bulb. Ocelli located on the tentacles, usually elongated, lying across the width of the tentacles. Marginal bulbs bright orange yellow, marginal tentacles pale yellow, stomach yellow, ocelli black.

DisTRIBUTION - It is a boreal species distributed in North Atlantic, from the American coast (Maine) to the Kattegat but it does not penetrate into the high Arctic. Foerster (1923, p. 27) mentions this species with a query from southern Alaska, as recorded by Bigelow. It is probably highly susceptible both to temperature and salinity, and local alterations in the hydrographical conditions can cause aberrations in the normal distribution of the species.

Discussion - This seems to be a rather variable species and this accounts for the fact that several different names were ap- 
plied to it by different authors. We refer to Russell for the explanation of the synonymy. It seems to us that Hartlaub (1897, p. 456) included under the name $B$. flavida medusae belonging to two different species, namely $B$. britannica and $B$. ramosa. Since the hydroid of $B$. ramosa is well-known, the one described by him as $B$. flavida must by exclusion be referred to the hydroid generation of $B$. britannica. Russell however points out (1953, p. 164) that "The adults from the plankton with which Hartlaub connected his flavida are certainly not britannica, and he later (1911) thought that his flavida was ramosa". Probably Hartlaub's (1897) B. flavida refers in part to B. britannica and in part to $B$. ramosa and accordingly we must exclude the sections referring to $B$. ramosa.

The British Museum specimens labelled $M$. bella n. ${ }^{\circ}$ 54.11.13.106-114 have rounded ocelli on the tentacle's bases. A few others, labelled B. britannica, . $^{\circ}$ 1954.12.23-34 and $\mathrm{n} .^{\circ}$ 1955.11.23.1-3, have a short basal trunk of the oral tentacles, but this may be due to the contraction caused by the fixative.

\section{Bougainvillia carolinensis (McCrady)}

Hippocrene carolinensis McCrady 1858, p. 164, pl. 10, figs. 8-10.

Margelis carolinensis Agassiz 1865, p. 156, figs. 241-248.

" " $\quad$ Haeckel 1879, p. 89.

Mayer 1900a, p. 43.

Bougainvillia carolinensis Allman 1872, p. 316.

" $\quad$ Nutting 1901, p. 330; 376.

" $\quad$ Hargitt 1901, p. 383, fig. 46.

$" \quad$ Hargitt 1904, p. 39, pl. 2, fig. 4.

$" \quad$ Mayer 1910 , p. 165 , pl. 16 , figs. $7-9 ;$ pl. 17 , fig. 7 .

" $\quad$ Fraser 1944, p. 50, pl. 5, fig. 19.

$" \quad$ " $\quad$ Berrill 1949, p. 15.

$" \quad$ Vannucci 1951, p. 78.

" $\quad$ Kramp 1955, p. 249 .

$" \quad$ Kramp 1959, p. 110, fig. 92.

Type Locality - Charleston Harbour, South Carolina, Atlantic coast of North America.

SPECIFIC CHARACTERS - Ocelli on bulb not on marginal tentacles, oral tentacles branched only twice and with long basal trunk; pear-shaped manubrium.

HYDROID - The stem grows to a height of $230-270 \mathrm{~mm}$. It tapers gradually from base do summit, it is fascicled and branches profusely. The main branches begin close to the base thus forming clusters of stems. The secondary branches are slender and ramify but little. Pedicels annulated or wrinkled. Hydranths, 
large, with long probosces, closely packed together, rose-coloured and with 12-15 tentacles. Medusa buds produced all over the stem and its branches.

MedusA - The fully grown medusae are dome-shaped and about four $\mathrm{mm}$. high. The bell walls, especially at the apex are very thick. The stomach is cylindrical or bottle-shaped in young specimens, becoming pear-shaped as the gonads develop. Gonads interradial. Basal trunk of the oral tentacles long; they ramify twice dichotomously. Marginal bulbs bean-shaped to triangular; they bear seven to twelve tentacles, ocelli are found on the adradial surfaces of bulbs. Radial canals and circular canal narrow. Pigmentation variable; manubrium may be green or red, the marginal bulbs may be brilliant red surrounded by a green edge, bordered with bright yellow. Ocelli dark brown or black. Digestive cavity may be brick red and the gonads cream coloured.

Distribution - Atlantic coast of North America, from Woods Hole, south to Tortugas (Florida) ; South Atlantic: the Gold Coast, coast of Brazil, State of São Paulo. Apparently a warm-water, euryhaline species.

Discussion - This is a well defined species, easy to determine mainly due to the characteristically pear-shaped manubrium and long basal trunk of the oral tentacles.

\section{Bougainvillia crassa Fraser}

Bougainvillia crassa Fraser 1938, p. 17, pl. 3, fig. 11.

Localities - Santa Elena Bay (Ecuador), Port Culebra (Costa Rica), Tangola-Tangola (Mexico). Dredged from three to twenty fathoms depth. Apparently the author did not select the type specimen nor the type locality. Only the hydroid is known and does not seem to have been found again since the original description.

HYDROID - Stem coarse, fascicled in the proximal portion; larger branches somewhat regularly arranged, while the finer ones are irregular. Numerous ultimate branchlets giving to the whole a flabellate aspect. Perisarc somewhat wrinkled but not annulated. Hydranths small with eight to ten tentacles. Medusa buds appear singly, attached by short pedicels to the ultimate branchlets.

Medusa - Unknown.

Distribution - Pacific Coast of tropical America. 
Discussion - This species will find its appropriate position in the system only after the type localities have been searched again, the hydroid suitably redescribed, and the medusae reared. At present it should be considered a doubtful species.

Bougainvillia frondosa Mayer

$\begin{array}{cll}\text { Bougainvillia frondosa } & \text { Mayer } 1900 \text { a, p. } 41, \text { pl. } 3 \text {, fig. } 5 . \\ \text { ", } & \text { Mayer 1910, p. 171, pl. 16, fig. } 6 . \\ \text { " } & \text { Berrill 1950, p. 309. } \\ & \text { " } & \text { Vannucci 1957, p. } 52 . \\ & & \text { Kramp 1959, p. 110, fig. } 95 .\end{array}$

TYPE LOCALITY - Tortugas, Florida.

SPECIFIC CHARACTERS - Lack of ocelli associated to the small number of marginal tentacles, small number of branches and long basal trunk of the oral tentacles.

HYDROID - Unknown.

Medusa - Umbrella about two $\mathrm{mm}$. high, with relatively straight vertical sides; manubrium cruciform in cross section, short and flask shaped. Basal trunk of the oral tentacles long, the tentacles branch dichotomously two to three times. Marginal bulbs are small and bear only two tentacles each. There are no ocelli. Radial canals and ring canal narrow. Gonads radial, planulae develop on the surface of the stomach. The endoderm of the manubrium and bulbs is pinkish white, tentacle tips turquoise.

Distribution - Florida. Southern coast of Brazil.

Discussion - The only other known species of the genus devoid of ocelli is B. muscoides which has a quadrate stomach, four to seven tentacles per marginal bulb and interradial gonads.

\section{Bougainvillia fulva Agassiz \& Mayer}

Bougainvillia fulva A. Agassiz \& Mayer 1899, p. 162, pl. 2, fig. 6.

Bougainvillea

Bougainvillia

"

,

,

$n$

,

,

,

,

"
A. Agassiz \& Mayer 1902, p. 145, pl. 2, fig. 8 .

Maas 1905 , p. 10 , pl. 1, fig. 8 ; pl. 2, figs. 9-10.

" Maas 1906, p. 87 , pl. 2, figs. 4-5.

" Bigelow 1909a, p. 195, pl. 6, fig. 7 ; pl. 44, figs. 5-7.

" Hartlaub 1909a, p. 448, pl. 19, figs. 1-4.

" Mayer 1910, p. 160.

" Bigelow 1919, p. 280.

" Kramp 1928, p. 47.

" Uchida 1938, p. 145.

" Nair 1951, p. 54.

" Kramp 1953, p. 264.

ramosa Ralph 1953 , p. 75 , pl. 4, fig. 25 . 


\section{TYPE LOCALITY - Fiji Islands.}

SPECIFIC CHARACTERS - Lack of peduncle. Adradial gonads. Six to eight dichotomous branches of the oral tentacles and 15 to 20 tentacles per marginal bulb.

MATERIAL SEEN - Abundant preserved material.

HYDROID - Unknown. According to Stechow (1914, p. 122), the hydroid described by Pictet (1893) from Amboina as B. ramosa is not ramosa and might be that of $B$. fulva.

Medusa - The umbrella may reach 8-14 $\mathrm{mm}$. in height, but is usually smaller; with thick jelly, vertical sides and a flatlyrounded top. There is no peduncle, the manubrium is relatively small, cruciform, and tends to become cubic when the gonads are fully developed. The oral tentacles branch dichotomously from six to eight times, the basal trunk of the oral tentacles is usually short, occasionally the ramification of the tentacles is not regularly dichotomous. The marginal bulbs are small, roughly rectangular in the smaller specimens (B.M. n. ${ }^{\circ}$ 1940.6.10.101) and tend to a triangular shape in larger ones (B.M. n. ${ }^{\circ}$ 1940.6.10.72-73 and 30.6.05), they bear 15 up to 20 tentacles. The ocelli are located on the base of the tentacles, they are small and slightly elongated in shape. The marginal tentacles are very short. There are eight distinct adradial gonads. The radial canals widen as they join the four corners of the stomach. The endoderm of the stomach and marginal bulbs is orange yellow or yellowish-green to brownish yellow. The gonads are dark yellow to brown.

Distribution - According to Kramp this is a common species in the coastal waters of the tropical parts of the Indian and $\mathrm{Pa}$ cific Oceans, including the eastern Pacific (Bigelow 1909a, Acapulco, Mexico). It is particularly common in the Malayan Archipelago and extends westerly to Madras and the east coast of Africa (Djibouti). It is a stenothermic, warm-water species. Almost throughout the year in the Trivandrum Coast, sexually mature from January to April.

Discussion - A well defined species, with its centre of dispersion in the Malayan region.

\section{Bougainvillia glorietta Torrey}

Bougainvillia glorietta Torrey 1904, p. 7, figs. 2-3.

$\begin{array}{lll}" & " & \text { Mayer 1910, p. } 172 . \\ " & " & \text { Foerster 1923, p. } 27 . \\ & " & \text { Fraser 1937, p. 36. }\end{array}$


Type LOCALITY - San Diego, California.

HYDROID - Stem branched, twenty to thirty $\mathrm{mm}$. high, it is not stated if it is fascicled or not. The branches twine around each other. Perisarc smooth or wrinkled, with no annulae, covered with particles of detritus. Terminal hydranths larger. According to the description there are 20 to 25 tentacles arranged in two or three irregular whorls, but the figure shows a single whorl of tentacles. Medusa buds in groups of two or three on the hydranth stem.

\section{Medusa - Unknown.}

DistRIBUTION - California; Vancouver Island Region.

Discussion - According to the descriptions and figures, this species seems similar to Bougainvillia (?) balei from West Australia; the principal difference lies in the great number of tentacles of this species. If Torrey's statement that the tentacles are arranged in more than one whorl should proove to be correct, this species must be placed in a different genus; possibly, however, the figure is more reliable than the text and in the latter a single whorl is shown. According to Torrey this species resembles $B$. superciliaris, the only difference being the absence of perisarcal rings and the twining habit of the branches of this species; these might be due to ecological factors. According to the same author, medusae with four pairs of tentacles, four simple mouth processes and eight ocelli could be detected in the medusa bud. B. superciliaris is known to be liberated with three tentacles and three ocelli per marginal bulb and until the life cycle can be worked out, B. glorietta should be considered a doubtful species.

\section{Bougainvillia inaequalis Fraser}

Bougainvillia inaequalis Fraser 1944, p. 51, pl. 5, fig. 20. Deevey 1950 , p. 337.

?Bougainvillia inaequalis Ralph 1953, p. 63, pl. 1, fig. 3 .

TYPE LOCALITY - Louisiana, United States.

HYDROID - The stem and sometimes the main branches are fascicled. Stems seven $\mathrm{mm}$ high and straight, there are only small branches or pedicels given off singly or in clusters. The perisarc is very much wrinkled and extends up to the base of the tentacles on the hydranth. The latter has from eight to ten tentacles. Medusa buds are borne singly or in clusters on the pedicels of the hydranths. 
Medusa - Unknown.

Distribution - Louisiana, off Passa Loutre; ?New Zealand (Portobello and Coromandel Peninsula).

Discussion - This species is listed by Deevey (1954, p. 269) in a check list of hydroids of the Gulf of Mexico alongside with $B$. rugosa, no descriptions being given. Ralph records the species from New Zealand, describes and figures the hydroid. The life history of this species is not known and it needs to be re-described to establish its identity. It is rather similar also to ?B. robusta (from the Pacific Coast of Mexico) whose life cycle also is unknown.

\section{Bougainvillia involuta Uchida}

Bougainvillia involuta Uchida 1947, p. 301, figs. 4a-d. cific.

Type Locality - Iwayama Bay, Palau Islands, Central Pa-

SPECIFIC CHARACTERS - Sixty tentacles in specimens four mm high oral tentacles branching dichotomously seven times. Ocelli on tentacle bases. Gonads interradial.

HYDROID - Unknown.

Medusa - Umbrella shaped, up to $4 \mathrm{~mm}$ high and $4.5 \mathrm{~mm}$ wide. Jelly thick. Short four sided peduncle present. Oral tentacles branch dichotomously up to seven times and apparently (fig. 4c) have a short basal trunk. There are up to sixty tentacles per marginal bulb. As far as can be seen by the figures the ocelli are placed on the tentacles bases. Marginal bulbs crescent shaped in young specimens; very large, sinuous and covering the greater part of the bell margin in large specimens. Gonads interradial, united to each other in large specimens and encircling the manubrium which thus becomes a large voluminous body.

Distribution - Central Pacific, Palau Islands.

Discussion - This species was described from 10 specimens and has not been recorded again since its original description. It appears to be clearly differentiated from its closest relative, $B$. superciliaris, by the large number of marginal tentacles per bulb and large number of bifurcations of the oral tentacles. The appearance of the gonads at maturity (said to encircle the manubrium) is also a good distinctive feature of this species which is much smaller than B. superciliaris; the latter is an arctic circumpolar species. It differs from $B$. fulva, also a tropical Pacific 
species in having interradial instead of adradial gonads, in having a peduncle and a large number of marginal tentacles. The only other species known to have so many tentacles on each bulb are $B$. macloviana and $B$. multitentaculata, probably a synonym of the former.

\title{
Bougainvillia linearis (Alder)
}

Atractylis linearis Alder 1862, p. 230, pl. 10, figs. 1-3.

See Bougainvillia britannica for a discussion of this species.

\section{Bougainvillia longicirrha Stechow}

\author{
Bougainvillia longicirrha Stechow 1914, p. 121, text-fig. 1. \\ " $\quad$ Stechow 1919, p. 25. \\ Fraser 1944, p. 52, pl. 6, fig. 21.
}

Type LOCALITY - Charlotte Amalie, St. Thomas, West Indies.

HYDROID - Stem monosiphonic, profusely branched, $15 \mathrm{~mm}$ high. The hydranths arise on short stalks from the stem and branches. The perisarc is rough and extends up to the base of the hydranths, it is encrusted with mud. The hydranths have about 16 tentacles. The medusa buds are formed on the pedicels below the hydranths.

Medusa - Unknown.

Distribution - West Indies, St. Thomas.

Discussion - Fraser cannot be right when he considers it a probable synonym of $B$. superciliaris, - the latter being a northern boreal species. It also differs morphologically in the hydroid from $B$. superciliaris. Stechow admits it may be the hydroid of $B$. niobe which is found in the same region and whose hydroid is unknown, but this is only surmise and it is safer to keep it provisionally under a separate name, because there is also $B$. frondosa to consider from the same area.

\section{Bougainvillia macloviana (Lesson)}

Cyanaea bougainvillii Lesson 1830, p. 118, pl. 14, fig. 3 .

Bougainvillia macloviana Lesson 1836, p. 262.

Lesson 1843, p. 290.

Hippocrene macloviana Haeckel 1879, p. 90, pl. 5, figs. 1-2.

Browne 1902, p. 278.

Perigonimus maclovianus Vanhöffen 1909, p. 284, fig. 10.

Bougainvillia macloviana Mayer 1910, p. 160.

$" \quad " \quad$ Hartlaub 1911, p. 156, fig. 139. 
?Hippocrene macloviana Vanhöffen 1912, p. 359, pl. 25, fig. 1.

Bougainvillia macloviana Jäderholm 1922, p. 3.

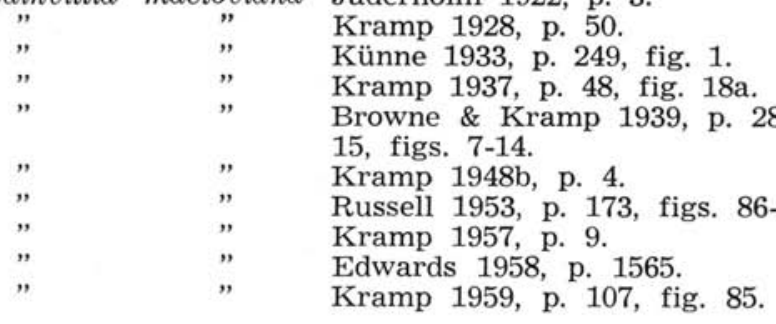

For a complete list of references see Browne \& Kramp 1939 and Russell 1953.

TYPE LOCALITY — Falkland Islands.

SPECIFIC CHARACTERS - Large peduncle present. Oral tentacles branch five-seven times. Thirty five to sixty tentacles per marginal bulb. Ocelli on bulbs. localities.

MATERIAL SEEN - Abundant preserved material from several

HYDRoId - The stems are long, thin, decumbent, monosiphonic except in old colonies where they may be polysiphonic. The perisarc is wrinkled and there is a thin perisarcal membrane forming the pseudothecae around the base of the hydranths. The latter have about 16 tentacles. The medusa buds are borne on short pedicels that are sometimes annulated.

Medusa - The bell is $15 \mathrm{~mm}$ high and about as wide, the margin is quadrangular, jelly thick. There are longitudinal furrows on the exumbrella. Large peduncle present even in young specimens, stomach pouches extend perradially along the peduncle. The oral tentacles have a very short basal trunk and branch five to seven times, there are 35-65 tentacles per marginal bulb, arranged in a double row. There are four longitudinal interradial furrows on the stomach. The marginal bulbs are V-shaped or crescent-shaped and the tentacles are arranged in a double row. Gonads, interradial, extending along the stomach lobes on the adradial sides of the peduncle. Radial canals rather wide and ring canal fairly narrow. Ocelli adaxial, situated on the bulb at the base of each tentacle. Stomach, gonads and marginal bulbs yellow, red, reddish-brown or orange; ocelli yellow, red or brownish black.

Distribution - Antarctic waters. North Sea. Firth of Clyde (Edwards 1958). Kramp states it to be subantarctic too 
and circumpolar (Antarctic Ocean). It may perhaps turn out to be circumbipolar. A cold water and probably an euryhaline, species.

Discussion - This is the type of the genus. A well defined species, both morphologically and as regards its habitat and geographical distribution, not likely to be easily confused with other species. It has been stated (Browne \& Kramp 1939, p. 285) and frequently repeated that it is not really indigenous in the North Sea but has apparently been transported there by ships when in the hydroid stage. This would imply that the hydroid is eurythermic and euryhaline and thus able to withstand a long journey through the temperate and tropical Atlantic. In the Southern Ocean it is found all the year round. It may be wondered if $B$. balei, known only as hydroid from West Australia, is not a synonym of this species.

\section{Bougainvillia maniculata Haeckel}

Bougainvillia maniculata Haeckel 1864, p. 327, 340.

Margelis maniculata Haeckel 1879, p. 89, pl. 5, figs. 4-5.

Lizzia maniculata Spagnolini 1871, p. 219.

Bougainvillia maniculata Perrier 1936, p. 34.

Kramp 1959, p. 109.

TYPE LOCALITY - Villefranche in the Mediterranean. There is no type.

HYDROID - Unknown.

Medusa - A small species, with an almost spherical umbrella $1.5 \mathrm{~mm}$ across. Velum wide. The stomach is devoid of peduncle and spherical. The oral tentacles have a very long basal trunk and branch twice dichotomously. The marginal bulbs bear four short finger-shaped tentacles, the bulbs are rounded and bulbs plus tentacles are hand-shaped. Ocelli on the inner base of tentacles. Four interradial gonads.

\section{DiSTRIBUTION - Mediterranean (Villefranche).}

DISCUSSION - Dwarf varieties of $B$. ramosa are known from Norway (Kramp \& Damas 1925) and the Adriatic Sea (Hartlaub 1911; Neppi \& Stiasny 1913) and this might be just another dwarf variety of $B$. ramosa. The only differences would be: interradial position of the gonads and position of the ocelli, which are here stated to be on the base of the tentacles. The small mature varieties of $B$. ramosa elsewhere also are known to have interradial gonads, while the statement that the ocelli are located on the base of the tentacles might just as well mean that they 
are on the bulbs "at the base of each tentacle" since at the time of the original description this had not yet been found to be a significant taxonomic character. We have seen a specimen in the plankton which was at first considered to be maniculata and which later proved to be just a small ramosa. A doubtful species.

\section{Bougainvillia meinertiae Jäderholm}

Bougainvillia meinertiae Jäderholm 1922, p. 3, fig. 4 .

TYPE LOCALITY - Cape Colony outside Borrocouto, Sebastian Bay (West and South Africa).

HYDROID - Stem erect reaching a height of 5-10 mm. Fascicled near its base. Numerous branches. Perisarc strongly, irregularly and transversely ringed. Hydranths protected at the base by a smooth expansion of the perisarc. Hydranths with about fourteen tentacles. Medusa buds borne on the ramuli below the hydranths, sessile, spherical to pyriform; there are apparently two tentacles per marginal bulb.

Medusa - Unknown.

Distribution - West and South Africa. To our knowledge this species has not been found again since its original description. ramosa.

Discussion - A doubtful species, perhaps referable to $B$.

\section{Bougainvillia multicilia (Haeckel)}

Margellium multicilium Haeckel 1877, pl. 6, fig. 13.

Lizusa multicilia Haeckel 1879, p. 81, pl. 6, fig. 13.

Bougainvillia multicilia Mayer 1910, p. 164.

Kramp 1959, p. 111.

TYPE LOCALITY - Straits of Gibraltar.

SPECIFIC CHARACTERS - No peduncle. Unbranched oral tentacles. Ten to twelve tentacles on each marginal bulb. Ocelli on abaxial side of bulbs. Gonads adradial.

HYDROID - Unknown.

Medusa - Bell six $\mathrm{mm}$ high and five $\mathrm{mm}$ wide. Velum narrow. Stomach without peduncle, spherical. Oral tentacles unbranched, terminating in a nematocyst knob. Radial canals narrow. Marginal bulbs large, kidney-shaped and bearing 10-12 tentacles. Ocelli on the outer or abaxial side of the bulbs. Eight 
adradial gonads. Stomach yellow, gonads and bulbs orange-yellow, ocelli dark red. lected.

Distribution - Not recorded again since it was first col-

Discussion - A doubtful species. The marginal tentacle bulbs are of the common Bougainvillia type, but the unbranched condition of the oral tentacles and the abaxial position of the ocelli make it a unique species in the genus. It should be removed from the genus Bougainvillia on the ground of such extraordinary characters, or perhaps considered a doubtful species until more specimens can be studied. The original description may refer to an abnormal specimen; Mayer suggests that Haeckel's description may refer to a young form, but the large number of marginal tentacles per bulb, the size and presence of gonads all suggest that it is either an abnormal specimen or really the type of a new genus. The question cannot be settled until more material is taken. This species is the reverse condition of Thamnostoma which has branched oral tentacles and four single marginal tentacles.

\section{Bougainvillia multitentaculata Foerster}

Bougainvillia multitentaculata Foerster 1923, p. 27, pl. 2, fig. 7; pl. 3, figs. 1-2.

TyPe LOCALITY - Banks Island (British Columbia). Type material in the Museum of the Dominion Biological Station, Namaino, B.C.

HYDROID - Unknown.

Medusa - Umbrella spherical, $10 \mathrm{~mm}$ in diameter, jelly moderately thick on the sides, quite thick at apex. Velum broad. Peduncle low and broad. The oral tentacles branch dichotomously six to seven times. According to pl. 2, fig. 7, the basal trunk of the oral tentacles seems to be short. The marginal bulbs are $\mathrm{V}$-shaped and bear 50-60 tentacles; tentacles and ocelli are placed on the bulb in a zig-zag row. Ocelli on bulb. The gonads are stated to be perradial, this is probably due to the fact that they extend along the peduncle, but they are probably interradial.

Distribution - British Columbia (Pacific Coast of North America) .

Discussion - We have been able to examine two specimens and a stomach of this medusa by courtesy of Dr. R. E. Foerster who kindly donated them to the British Museum. These specimens, from the original type lot have become somewhat flattened 
during the years and are not in a good state of preservation. The most complete specimen, which has been given the number 1960.6.15.1, is here designated as Lectotype.

The number of tentacles, given as $50-60$ by Foerster is confirmed; the tentacle bulbs, which are in the form of an open V, are deeply cleft radially giving almost the appearance of two adradial crescentic bulbs. By comparison, the tentacle bulb in B. macloviana, which has a comparable number of tentacles per bulb, forms a sharp $\mathrm{V}$, is only very slightly indented and the two sides are rather closely adpressed - at least in all the preserved specimens seen by us.

When the quadrangular stomach of $B$. multitentaculata is examined, a peduncle is found to be almost non-existent being only a very shallow depression. Internally there is a large hollow cavity with 8 adradial on the outside attached on either side of the radii. The gonads are not carried beyond the limits of the central stomach region as in $B$. macloviana. The oral tentacles are not sufficiently well preserved for description but it can be said that the basal trunk is fairly short.

In Foerster's drawing of the stomach (1923, pl. III, fig. 1), the lightly-shaded area is thus the stomach cavity and not a peduncle. Comparison with $B$. principis reveals a close similarity as regards the form of the stomach and the short basal trunk of the oral tentacles. However the Canadian species appears to differ in the distinctly bilobed tentacle bulb and in the greater number of tentacles.

Bougainvillia multitentaculata thus appears to be a good species and the examination of fresh material should confirm this view.

\section{Bougainvillia muscoides (Sars)}

Perigonimus muscoides M. Sars 1846, p. 8, pl. 1, figs. 19-21.

Perigonimus muscoides Allman 1872, p. 322.

Bougainvillia obscura Bonnevie 1898, p. 7, pl. 1, figs. 4-4a.

Margelis nordgaardi Browne 1903, p. 14, pl. 2, fig. 1; pl. 3, figs. 5-6.

Perigonimus muscoides Jäderholm 1909, p. 46, pl. 1, fig. 18.

Bougainvillia nordgaardi Mayer 1910, p. 168, fig. 91.

obscura Mayer 1910, p. 172.

nordgaardi Hartlaub 1911, p. 192, fig. 171.

" Foerster 1923, p. 28, pl. 3, figs. 3-4.

,

" $\quad$ " $\quad$ Kramp \& Damas 1925, p. 256.

" " $\quad$ Kramp 1937, p. 49, fig. $18 \mathrm{~b}$.

" muscoides Rees 1938, p. 2, fig. 1.

" $"$ Rees 1956a, p. 342.

" $\quad$ Rees 1956b, p. 113

" " $\quad$ Edwards 1958, p. 1564.

" nordgaardi Kramp 1959, p. 110, fig. 94. 
TYPe LOCALITY - Korsfjord, SW of Bergen, Norway, 0-50 m (type locality here restricted).

Specific Characters - Peduncle present. No ocelli. Long basal trunk of the oral tentacles.

Material Seen - Abundant material from Norway.

HYDRoID - A rhizocaulome. The stems reach a height of $2 \mathrm{~cm}$ (according to Allman, 2-3 inches). Both the central and peripheral tubes produce hydranths, each with 8-12 tentacles. The terminal hydranths reach $0.5-1 \mathrm{~mm}$ in length, but the lateral ones are smaller. Perisarc slightly wrinkled, forms a small cup around the basal third of the hydranths. Great numbers of medusa buds arise from the rhizocaulome and its branches. Polyps reddish, red and white medusa buds. According to Allman, hydrocaulus much branched.

MEdusa - Umbrella four mm high by four $\mathrm{mm}$. wide, evenly rounded. Velum narrow. The specimens larger than $1.7 \mathrm{~mm}$ and with two marginal tentacles per bulb, already have a slight peduncle. There are 5-7, rarely eight bulbar tentacles. The bulbs are triangular. There are no ocelli. There is a slight peduncle. The four oral tentacles branch 4-5 and even 6-7 times. The basal trunk of the oral tentacles is long. The gonads are interradial and the manubrium becomes elongated when the gonads are ripe. The newly liberated medusa has a $0.55-0.65 \mathrm{~mm}$ diameter, thin jelly; well developed velum; short stomach with four unbranched tentacles with few terminal nematocysts; four marginal bulbs with one tentacle each and no ocelli; bulbs with reddish-brown pigment; medusae measuring $0.85 \times 0.8 \mathrm{~mm}$ have oral tentacles beginning to branch. In the adult medusa, the gonads and tentacle bulbs are yellowish-brown, bright orange-red, according to Kramp \& Damas.

Distribution - Norway; Gullmarfjord, Sweden (Jäderholm 1909); Firth of Clyde (Edwards 1959); Wyville-Thomson ridge ("Valdivia" st. 11; according to Hartlaub 1911, p. 193) ; west coast of North America. Vanhöffen recorded this species from southern Chile, but Kramp (1952, p. 15) regards this as incorrect. A coldwater, probably euryhaline, species.

Discussion - This species was originally described by Sars who collected only the hydroid generation and named it Perigonimus muscoides. The medusa was described by Browne under the name $B$. nordgaardi. Rees identified the two by dredging the hydroid and rearing the medusae liberated from it. It is a very clearly defined species. Foerster identified as B. nordgaardi (=muscoides $)$ a single specimen collected north-east of Five Finger 
Island, Pacific Coast of North America. He says that his specimen agrees in all respects with Hartlaub's figure but does not mention the presence or absence of ocelli, his figure shows none and probably his identification is correct. The only other species of the genus devoid of ocelli is the small $B$. frondosa, a warm-water form from the Florida region.

\section{Bougainvillia (?) nanella (Stechow)}

Perigonimus (?) nanellus Stechow 1919, p. 14, fig. C.

TyPe LOCALITY - Naples.

HYDROID - Stem eight $\mathrm{mm}$ high. Monosiphonic. Richly branched and with numerous hydranths. Perisarc wrinkled or irregularly annulated on stem and branches, with very fine sand particles adherent. The perisarc does not cover the hydranths, it only reaches their lower border. Eight to twenty tentacles. Conical proboscis. Gonosome unknown.

MedUSA - Unknown.

Distribution - Naples.

Discussion - Rees (1956a, p. 342) has pointed out that this may be a well formed colony of one of the common species but nothing can be said definitely until more is known on the life history of this doubtful species. Later Picard (1958) included this species in the synonymy of Heterocordyle conybeari and he is probably right since he has observed the gonosome.

\section{Bougainvillia niobe Mayer}

Bougainvillia niobe Mayer 1894, p. 236, pl. 1, fig. 2.

\begin{tabular}{|c|c|c|}
\hline " & $"$ & Mayer $1900 a$, p. 42 \\
\hline$"$ & $"$ & Mayer 1904 , p. 11 , pl. 2, figs. $14-15$ c. \\
\hline$"$ & $"$ & Mayer 1910, p. 166, pl. 18 , figs. $1-3$ \\
\hline$"$ & $"$ & Bigelow 1918 , p. 368. \\
\hline$"$ & $"$ & Bigelow 1938, p. 104. \\
\hline$"$ & $"$ & Kramp 1959, p. 110, fig. 93. \\
\hline
\end{tabular}

TyPe LOCALITY - Bahamas, Nassau Harbour.

MATERIAL SEen - Abundant material seen from Bermuda and "Dana" st. 1294 V.

SPECIFIC CHARACTERS - No peduncle. Adradial gonads. Medusa buds produced interradially in large specimens. Oral ten- 
tacles branch four to eight times, long basal trunk. Elongate ocelli on bases of tentacles.

\section{HYDROID - Unknown.}

Medusa - The cylindrical bell may reach nine to twelve $\mathrm{mm}$ in height and six to seven in diameter. Jelly thick. There are eight to ten thick tentacles on each marginal bulb, there may be 13-16 and even up to 19 in mature specimens. Each marginal tentacle bears an elongate ocellus near its base, on the velar side. The bulbs are small, semilunar. There is no peduncle. The oral tentacles branch four to six times, even eight to nine according to Bigelow; the basal trunk is long. The manubrium is cruciform, small and wide. There are eight adradrial gonads. According to Bigelow, specimens smaller than nine $\mathrm{mm}$ produce medusa buds, while specimens larger than eight $\mathrm{mm}$ have gonads. Medusa buds are formed interradially on the manubrium. This species may be infested with parasitic Cunina. Manubrium and tentacles bulbs rosine coloured. Indies.

Distribution - Florida, Bahamas, Bermudas, Cuba and West

Discussion - A valid species. It is closely allied to B. fulva and B. platygaster. Kramp (1957, p. 11) has recently discussed the similarity and differences existing between the three species. $B$. fulva is found exclusively in Indo-Pacific coastal waters, is larger, tends to have more tentacles on each bulb and is not known to reproduce by asexual budding. $B$. niobe is confined to the temperate and sub-tropical north western Atlantic. B. platygaster is also exclusively Atlantic but apparently has a wider range, being found in the tropical and sub-tropical region; morphologically it differs from $B$. niobe in having no basal trunk of the oral tentacles and crescent shaped ocelli. It has the peculiar habit of producing medusa buds asexually. For more details see Kramp (l.c.).

\section{Bougainvillia obscura Bonnevie}

Bougainvillia obscura Bonnevie 1898, p. 7, pl. 1, figs. 4-4a.

" " Mayer 1910, p. 172.

$" \quad$ " Rees 1956b, p. 113.

TYPe LOCALITY - Norway. Type in the Zoological Museum, Oslo.

HYdRoId - A small hydroid, about $20 \mathrm{~mm}$ high. The stem is rigid with almost opaque perisare with no foldings nor rings. The terminal hydranths are larger and all have about 15 tentacles. 
The lateral polyps have wrinkled stems. Medusa buds are produced either singly or in clusters upon branched processes immediately under the hydranths.

Discussion - An insufficiently described species. Rees (1956b) who examined the type material, follows Hartlaub's opinion (1911, p. 192, foot note) who believed this to be a young colony of $B$. muscoides prior to rhizocaulome formation.

\section{Bougainvillia platygaster (Haeckel)}

Hippocrene platygaster Haeckel 1879, p. 91.

Bougainvillia platygaster Mayer 1910, p. 165.

" niobe Vanhöffen 1912, p. 359.

" platygaster Thiel 1938, p. 299.

" niobe Kramp 1948 b, p. 4.

" platygaster Kramp 1957, p. 9, fig. 9; pl. 3, figs. 1-6.

" $\quad$ Kramp 1959, p. 108, fig. 89.

TyPe LOCALITY - Cape Verde and Canary Islands. Type specimens at the Zoological Museum, Copenhagen.

SPECIFIC CHARACTERS - Extremely flattened stomach. No basal trunk of the oral tentacles. Interradial gonads. Crescent shaped ocelli.

HYDROID - Stems or stolons arising directly from the unmature germinal tissues of the medusa. Hydranths, fusiform, with whorls of 10-12 tentacles and borne on short pedicels. Medusa buds borne on stalks immediately below the hydranths or on pedicels from stolons.

Medusa - The umbrella is about as high as wide and flattened above, rather cubic, $12 \mathrm{~mm}$ high. The marginal bulbs are wide triangles each bearing seven to nine and up to 10-12 tentacles; ocelli crescent shaped with concavity directed outwards, placed on the tentacles. There is no peduncle, the oral tentacles branch three to four times and even five to six times; they branch directly from their point of origin, there being no basal trunk or extremely short. There are four interradial gonads. The stomach is very flattened being four times as wide as high and four sided; the mouth is usually widely opened in preserved specimens. The stomach, gonads and tentacle bulbs are reddish-yellow. This species undergoes vegetative reproduction and the new medusa buds are produced in clusters on the stomach, budding from polypoid hydranths or stolon-like structures. 
Distribution - Atlantic Ocean: Canary Islands, Cape Verde Islands, Trindade, West Indies and Sargasso Sea; Indian Ocean: eastern coast of Africa between $7^{\circ} 42^{\prime}$ S $-34^{\circ} 30^{\prime}$ 'S.

Discussion - Recently Kramp (1957, p. 11) has described both the medusa and its interesting mode of asexual propagation in details. The same author has also clearly set out the differences between this species and its closest allies: B. fulva, B. niobe and B. carolinensis.

\section{Bougainvillia principis (Steenstrup)}

For a complete synonymy of this species see Russell 1953 , p. 164 .

Margelis principis Steenstrup 1850, p. 35.

Bougainvillia fruticosa Romanes 1876, p. 526.

Bougainvillia allmani Romanes 1877, p. 190.

Margelis principis Haeckel 1879, p. 88, pl. 6, figs. 14-16.

Nemopsis heteronema Haeckel 1879, p. 93 (in part).

Margelis britannica Browne 1896, p. 180.

Margelis principis Browne 1900, p. 708.

Hippocrene aurea Linko 1904, p. 216.

Bougainvillia principis Mayer 1910, p. 160.

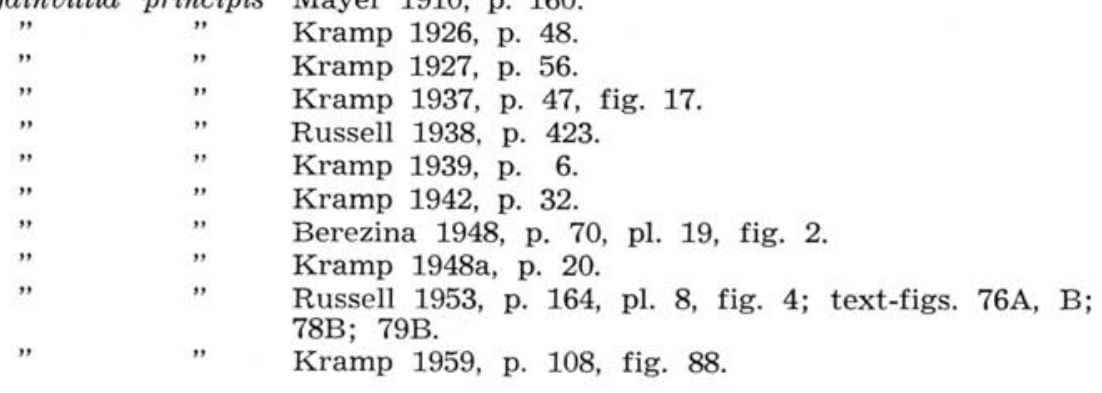

Type specimen - Zoological Museum, Copenhagen.

MATERIAL SEen - The type specimen and abundant preserved and living material from the British Isles.

Type LOCALITY — Faeröe Islands.

SPECIFIC CHARACTERS - No peduncle. Ocelli rounded on bulb. Eight adradial gonads. Oral tentacles branch five to six times. Usually 20-30 tentacles on each marginal bulbs.

HYDROID - Unknown.

Medusa - Umbrella from eight to eleven mm high, globular. Jelly rather thick. Marginal bulbs épaulette or kidney-shaped, 
ocelli black, small, rounded on the adaxial surface of the bulb. There are up to 40 tentacles, usually 20-30 per marginal bulb. No peduncle, or very slight. Oral tentacles branch five to six times and the basal trunk is very short. Manubrium is short, has a broad cruciform base. Gonads are adradial. Marginal bulbs are wine red, dark reddish brown or orange, with a central mass of dark pigment, the stomach is wine red or golden yellow; the ocelli are black.

Distribution - South West of Ireland, Irish Sea, eastwards to the Norwegian Coast, Barents Sea and Skagerrak; Rockall; Iceland; West Greeland, Murman Sea. A northern boreal species probably restricted in its distribution, recorded as yet only from the northern Atlantic and adjacent seas.

Discussion - A well defined species.

\section{Bougainvillia prolifera (von Lendenfeld)}

Lizusa prolifera von Ledenfeld 1884 a, p. 589, pl. 23, figs. 38-39. Bougainvillia prolifera Mayer 1910, p. 170.

TyPe LOCALITY - Port Jackson, New South Wales.

HYDROID - Unknown.

MedusA - Umbrella globular, about three $\mathrm{mm}$ in diameter. There are five tentacles on each "scrotum-shaped" basal bulb. Ocelli? Peduncle? (probably absent). Oral tentacles unbranched. Manubrium small, nearly cubic. Gonads?. Numerous medusa buds on the stomach and also buds on the buds. Tentacle buds and stomach brown.

\section{Distribution - Port Jackson, New South Wales.}

Discussion - This species is insufficiently known. Mayer thinks it may be a juvenile with as yet unbranched oral tentacles, but this probably is not true, due to the large size of the specimens and the presence of medusa buds on the stomach. There is another species, also imperfectly known, namely $B$. multicilia described by Haeckel from the straits of Gibraltar which also has unbranched oral tentacles. Neither of these have been studied again since the original description. Should it be proved that the oral tentacles remain permanently unbranched, a separate genus would be needed and Haeckel's genus Lizusa is available for them. This genus would have to be placed in the family Bougainvilliidae and would be characterized by the presence of four clusters of marginal tentacles and simple unbranched oral tentacles; however due to 
our incomplete knowledge of these two species at present, we believe it is better provisionally to keep them under separate names in the genus Bougainvillia. Kramp (1953, p. 264) also regards this species as doubtful.

\section{Bougainvillia pyramidata (Forbes \& Goodsir)}

For a complete bibliography see Russell 1953, p. 167.

Hippocrene pyramidata Forbes \& Goodsir 1851, p. 312, pl. 10, fig. 4.

Margelis pyramidata Browne 1900, p. 709.

Bougainvillia pyramidata Mayer 1910, p. 168.

" " $\quad$ Russell 1953, p. 167, text-figs. 82 A-C.

Kramp 1959, p. 108, fig. 86.

TYPE LOCALITY - Loch Laigh in Mull.

MATERIAL SEeN - Preserved material from the British Isles.

SPECIFIC CHARACTERS - Peduncle present. Ocelli on bulbs. The gonad extends along the peduncle. Six to nine tentacles on each marginal bulb. Oral tentacles branch three to four times.

HYDROID - Unknown.

Medusa - Umbrella globular, three to five and up to eight $\mathrm{mm}$ high and wide. Jelly rather thick. From six to nine tentacles on each bulb. Marginal bulbs oval to rounded. Rounded ocelli on adaxial surface of bulbs. Broad cone-shaped peduncle. The oral tentacles branch three to four times. Basal trunk of oral tentacles short. The gonad has the shape of a tetrapod, since the gonadial tissue extends on the outer side of the peduncle along the radial canals. Marginal bulbs brown or yellowish, ocelli black.

Distribution - Western coasts of the British Islands.

Discussion - Russell (1953, p. 158) points out the fact that what he includes under the name $B$. ramosa may still after all refer to two distinct but very similar species. According to this author, one species would be $B$. ramosa as reared from the homonymous hydroid and the other B. autumnalis of Hartlaub (1897). It seems however that Hartlaub must have included under the heading $B$. autumnalis two different species, one being $B$. ramosa and the other B. pyramidata. Thus fig. 5, pl. 14 of Hartlaub (1897) would refer to $B$. ramosa and fig. 6 , pl. 14 to B. pyramidata (see also Hartlaub 1911, p. 185, fig. 163). B. ramosa would therefore be a synonym of only part of what Hartlaub called $B$. autumnalis and Hartlaub was only partly correct when in 1911 (p. 185) he combined $B$. autumnalis with $B$. ramosa. This being 
so would explain the uneasy situation concerning the ramosa group of species, a fact of which Russell is well aware. A very queer fact however still stands, that the hydroid of B. pyramidata is still unknown and that of $B$. britannica is not known for certain.

Material from Helgoland, determined as B. autumnalis by Hartlaub was examined by the authors (British Museum n. 1954.11.13.141-143) who found them to have a slight peduncle and a four cornered pyramid shaped manubrium (what has been termed above: tetrapod shaped manubrium). Other specimens in the collections of the British Museum labelled B. autumnalis, collected at Plymouth 31-8-1897 are undoubtedly $B$. ramosa; the same is true for what concerns specimens determined by E. T. Browne as Margelis autumnalis (B.M. n. ${ }^{\circ}$ 1948.10.1.217), collected at Ballynakill, as well as specimens from Plymouth. Hartlaub's specimens should probably be considered to be pyramidata.

The principal differences between this species and B. ramosa is the presence of peduncle in B. pyramidata and the tetrapod shape of the gonad of the latter, which extends along the radial canals up into the peduncle's region.

\section{Bougainvillia ramosa (van Beneden)}

For a complete list of references see Russell 1953, p. 153.

Eudendrium ramosum van Beneden 1844, p. 57, pl. 4, figs. 10-13.

Bougainvillia ramosa Allman 1872, p. 311, pl. 9, figs. 5-6.

fruticosa Allman 1872, p. 314, pl. 9, figs. 1-4.

muscus Allman 1872, p. 317, pl. 10, figs. 1-3.

autumnalis Hartlaub 1897 , p. parte, p. 465 , pl. 14, fig. 5. (See discussion of $B$. pyramidata).

? $\quad$ vanbenedeni Bonnevie 1898, p. 484, pl. 26, figs. $34-35$.

gibbsi Mayer 1900b, p. 5, pl. 4, figs. 14-15.

van Benedeni Jäderholm 1909, p. 46, pl. 3, fig. 3.

ramosa Jäderholm 1909, p. 47, pl. 3, fig. 4.

ramosa Stechow 1909, p. 26.

autumnalis Mayer 1910 , p. 169 , pl. 16, figs. 4-5; pl. 17, figs. $3-4$.

ramosa Hartlaub 1911, p. parte, p. 183, figs. 162, 164-167; non fig. 163.

" flavida Hartlaub 1911, p. parte, p. 456. (See above B. britannica).

" triestina Hartlaub 1911, p. 189, fig. 168.

" ramosa Stechow 1919, p. 27.

" vanbenedeni Stechow 1919, p. 25, 154.

" benedeni Brink 1924, p. 727.

" ramosa Brink 1924, p. 728.

" fruticosa Brink 1924, p. 728.

" muscus Brink 1924, p. 728.

" ramosa var. minima Kramp \& Damas 1925, p. 254, figs. 5-7.

" ramosa Kramp 1926, p. 43.

" ramosa Briggs 1931, p. 282.

" ramosa Broch 1933, p. 11.

" ramosa Hummelinck 1936, p. 44. 
?Bougainvillia ramosa Ling 1937, p. 355 .

Bougainvillia ramosa Kramp 1937, p. 44, fig. 15a.

ramosa Kramp 1939, p. 6.

ramosa Vervoort 1942, p. 281.

ramosa Vervoort 1946a, p. 135.

ramosa f. benedeni Vervoort 1946b, p. 338.

autumnalis Babnik 1948, p. 16, fig. 2.

autumnalis var. magna Babnik 1948, p. 17, fig. 2.

ramosa Russell 1953 , p. 153 , pl. 8 , fig. 1 ; pl. 9 , figs. $4-5$; text-

figs. 74 A-C.

" ramosa Vannucci 1957, p. 53.

" ramosa Kramp 1959, p. 109, fig. 91.

\section{TyPe LOCALITY - Ostende.}

MATERIAL SEEN - Abundant material seen both alive and preserved from several different localities.

HYDROID - The hydroid has been described under several different names due to the marked effect that the environmental conditions have on the habitat of the colony, as Hallez (1905) and later Brink (1925) have demonstrated. These different forms are mere adaptive variations. To sum up, the hydroid may tentatively be described as follows: stems erect, either simple or fascicled, may reach $15 \mathrm{~mm}$, branching profusely, slightly corrugated perisarc. The perisarc extends as a membranous cup or a well defined perisarcal cup around the base of the hydranths. The hydranths are fusiform, with a single whorl of 15-18 filiform tentacles; there may be only 12 in small colonies. Medusa buds on peduncles borne by the caulus. Branches and stems may exhibit stoloniferous growth. Colonies have been dredged from depths down to $150 \mathrm{~m}$. The hydranths are pink or bright red.

Medusa - Umbrella rounded, may be up to four $\mathrm{mm}$ high. Jelly thick, velum well developed. No peduncle or very slight. Oral tentacles branch two or three times usually, sometimes four. Basal trunk of the oral tentacles medium sized to rather long. Stomach short. Gonads adradial or interradial; in dwarf varieties and when fully developed they are interradial; the stomach may appear cruciform or rounded when viewed from above, according to the position and state of development of the gonads. Ring canal and radial canals narrow. There may be up to nine marginal tentacles on each bulb, usually less, only three to five. Marginal bulbs oval to rounded, they bear round ocelli on their adaxial surface at the tentacle's base. Bulbs and stomach usually dark reddish brown or yellowish, sometimes with a greenish tinge. Ocelli black.

Distribution - North Atlantic: British Isles, North Sea, Norway, Bay of Biscay, Mediterranean (including the Adriatic 
Sea), Cape Verde Islands, Rhode Island (U.S.A.). South Atlantic: western coast of South Africa, southern coast of Brazil. IndoPacific: Australia, Amboina, Japan, China. It is probably a widely distributed species to be found in temperate and subtropical regions. Euryhaline and eurythermic.

Discussion - Owing to the fact of its being a very variable species it has been described under different names. According to Kramp (1937, p. 44) also B. flavida as in Hartlaub (1911) should be considered as synonym of this species (but see p. 63). Neppi \& Stiasny correctly include $B$. triestina which they consider to be a juvenile, in the synonymy of $B$. ramosa. Concerning the synonymy of $B$. benedeni Rees states: "I see no reason for not regarding this species as identical with $B$. ramosa, but the hydroid of $B$. superciliaris undoubtedly occurs also in Norwegian waters (because its medusa has often been recorded) and the two species are very alike." In both, the medusa buds are often borne in clusters and the young medusae are very similar at liberation (Brink 1925; Berrill 1949). See also discussion of B. pyramidata.

\section{?Bougainvillia robusta (Fraser)}

?Perigonimus robustus Fraser 1938, p. 17, pl. 3, fig. 12.

TYPe LOCALITY - Petatlan Bay; Isabel Island.

HYDROID - Slender unbranched colony, reaching a height of $60 \mathrm{~mm}$. Stem simple, neither very straight nor rigid; annulated or wavy throughout its whole length. Zooids given off irregularly from all sides of the stem. Pedicels increase in diameter as they pass out so that the distal portion bears some resemblance to a hydrotheca; annulations or wrinkles close together in the proximal half or two thirds, farther apart in the distal portion. Hydranths with 9-10 tentacles. No medusa buds were observed.

Distribution - Pacific coast of Mexico, Petatlan Bay; Isabel Island between five to 25 fathoms.

Discussion - A doubtful species since the gonosome is unknown. Rees (1956a, p. 343) has placed it provisionally in the genus Bougainvillia.

\section{Bougainvillia rugosa Clarke}

Bougainvillia rugosa Clarke 1882, p. 140, pl. 8, figs. 21-24.

$\begin{array}{lll}", & \text { Mayer } 1910, \text { p. } 171, \text { pl. } 17, \text { fig. } 2 . \\ " & , & \text { Stechow } 1919, \text { p. } 27 . \\ " & " & \text { Fraser } 1944, \text { p. } 53, \text { pl. } 6 \text {, fig. } 22 . \\ " & \text { Deevey } 1954, \text { p. } 269 . \\ & \text { Kramp 1959, p. } 110, \text { fig. } 96 .\end{array}$


TYPE LOCALITY - Hampton Road, Virginia.

HYDRoID - A clearly defined, polysiphonic stem reaching a height of $75 \mathrm{~mm}$. Numerous irregular small branches, with basal portion polysiphonic. Hydranths fusiform, protected by an annulated perisarcal expansion, present on stem and branches. Eight to ten tentacles. Medusa buds borne by the ultimate ramuli near the base of the hydranths. Buds present in August and September.

Medusa - Observed in aquaria for a few days after liberation; only young specimens. Velum well developed. Manubrium short and thick. Radial canals narrow. Unbranched capitate oral tentacles. Clarke states that there are ocelli only at the bases of two of the three marginal tentacles of each bulb. The specimens collected by Mayer and by him referred to this species have three ocelli on the adaxial surface of the marginal bulbs, one at the base of each tentacle.

Distribution - Hampton Road, southern part of Chesapeake Bay; Charleston Harbour, South Carolina. It has been listed by Deevey from the Gulf of Mexico.

Discussion - The medusae reared by Clarke did not show any sign of branching of the oral tentacles and neither development of the lacking ocellus nor of gonads before dying. It was probably placed in the correct genus and the lack of branching of the oral tentacles must be regarded as a juvenile character. The lack of only one ocellus seems to be a queer distinctive character since it is described to be regularly absent in the third tentacle of each bulb counting from "left to right". This is an insufficiently known species but probably a valid one. Kramp considers it to be a doubtful species.

\section{Bougainvillia superciliaris (L. Agassiz)}

For a complete list of references see Mayer (1910, p. 162) Russell (1953, p. 169).

?Cyanaea bougainvillei Brandt 1838, p. 293.

Hippocrene superciliaris L. Agassiz 1849, p. 273, pls. 1-3.

Bougainvillia mertensi L. Agassiz 1862, p. 344 .

" superciliaris A. Agassiz 1865, p. 153, figs. 232-240.

" superciliaris Allman 1872, p. 315.

" paradoxa Mereschkowsky 1879, p. 177, pl. 20, figs. 1-5.

" superciliaris Haeckel 1879, p. 92.

" superciliaris Hartlaub 1909b, p. 4.

" superciliaris Bigelow 1909b, p. 305, pl. 21, fig. 2.

" superciliaris Mayer 1910 , p. 162 , pl. 17, fig. 1 , text-figs. 87-88.

" bougainvillei Hartlaub 1911, p. 159, fig. 140. 
?Bougainvillia superciliaris Hartlaub 1911, p. 171, figs. 153-157.

Bougainvillia

Bigelow 1913, p. 9.

bougainvillei Foerster 1923, p. 27.

superciliaris Foerster 1923, p. 28.

Bougainvillia superciliaris Foerster 1923, p. 28.

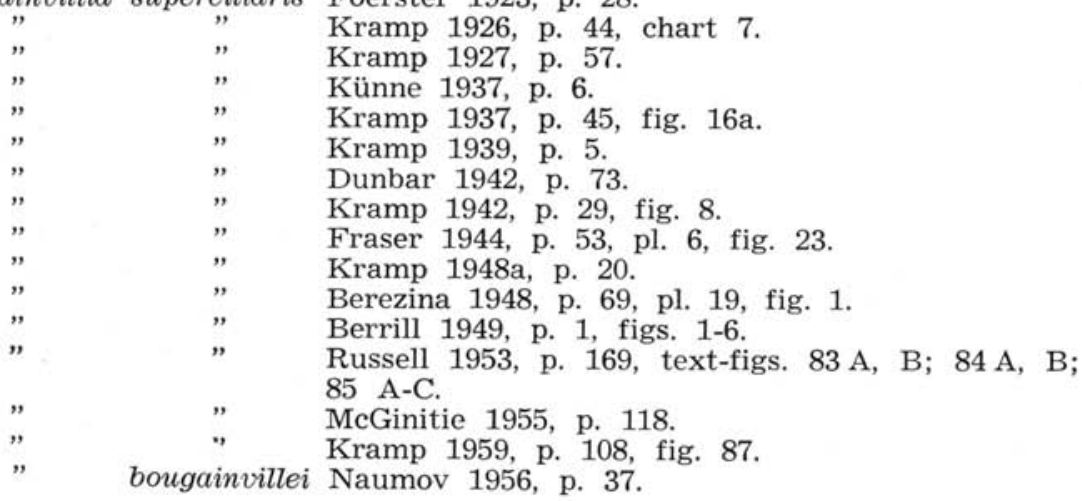

TYPE LOCALITY - Atlantic coast of North America.

MATERIAL SEEN - Abundant preserved material from different localities.

SPECIFIC CHARACTERS - Peduncle present. Gonads interradial. Ocelli on base of tentacles. Oral tentacles branching usually four to five times. Usually eleven to fifteen tentacles on each marginal bulb.

HYDROID - Hydrocaulus abut $5 \mathrm{~cm}$ high, simple. Profusely but somewhat irregularly branched, branches tend to be arranged alternately and spirally. Branches annulated proximally with 5-10 rings. Perisarc thins out distally and disappears entirely below the whorl of filiform tentacles of the hydranths. Fifteen to twenty tentacles. Hypostome short. Medusa buds arranged singly and irregularly over the branches near the base of the hydranths. Medusa buds enclosed in a thin perisarcal sheath. The newly liberated medusa "usually" has two tentacles on each marginal bulb and four short knob-shaped oral tentacles while the "young tentacles are each provided with a centripetal, ectodermal ocellus".

Medusa - Umbrella almost globular may reach a height of $12 \mathrm{~mm}$, usually up to ten. Jelly thick. Velum well developed. Peduncle present. Radial canals broad, ring canal narrow. Stomach short, broad base, cruciform in section. Oral tentacles branch four to five times. Basal trunk of the oral tentacles short. Gonads interradial, planulae develop in situ within capsules. Marginal bulbs crescent shaped to heart shaped, less than half as wide as the interradial space. There may be as many as 22 tentacles on 
each bulb, usually not more than fifteen. Ocelli large, situated on base of tentacles. Stomach brown to reddish brown; marginal bulbs chestnut brown, ocelli black.

DISTRIBUTION - An arctic species to be found in cold circumpolar waters. It was recorded from: White Sea, Barents Sea, Spitzbergen, Bear Island, coasts of Norway, Denmark, Holland, North Sea, Baltic, occasionally northern part of the British Isles; Iceland; Greenland, Labrador southward down to Cape Cod; North Pacific, Bering Sea, Alaska. Where the water is cold it may be found throughout the year. A neritic species, euryhaline, stenothermic with a low temperature optimum.

Discussion - According to Russell, Louis Agassiz's figures (1865, figs. 233-239) as well as the hydroid and young medusa described by Mayer (p. 163) do not refer to this species. The hydroid described by Hartlaub under this name was found in a tank and presumed by him to belong to this species. It was a very small creeping colony with a sessile hydranth with six (?) filiform tentacles. Medusa buds were borne singly on short stalks arising from the hydrorhiza. Alexander Agassiz's description of the adult refers to this species, but his hydroid and young medusa belong to another species, possibly $B$. ramosa. Hartlaub's hydroid perhaps belongs to principis, it is very small and inconspicuous and this would explain why the hydroid of such a common species is still unknown. The young medusa figured by Hartlaub (1911, figs 154,156 ) has three tentacles on each marginal bulb, oral tentacles branched twice and ocelli clearly placed on the bulb and not on the bases of the tentacles. Mayer's description of the newly liberated medusa agrees with the characteristics of the adult, whilst it disagrees with Hartlaub's description. The position of the ocelli in the medusa as figured by Hartlaub is a strong argument against the identity of his specimen with $B$. superciliaris since the latter is known to have tentacle borne ocelli, like B. britannica and unlike $B$. principis which has them on the bulb. Hartlaub's hydroid and newly liberated medusa probably must be referred to $B$. principis.

Allman (1872, p. 318) and Mayer (1910, p. 162) finally after a long discussion, consider $B$. mertensi to be a synonym of this species.

Agassiz (1865) and Mayer (1910) also include in the synonymy of this species Hippocrene bougainvillei described by Gould (1841, p. 348) from Massachusetts. They are possibly right, but Gould's description and figure could be any Bougainvillia and is therefore of uncertain identity.

Russell does not include $B$. bougainvillei in the synonymy of B. superciliaris but Kramp (1942, p. 32) mentions that B. bou- 
gainvillei is recorded from the Bering Sea to S. Francisco, "but it is possible that it is identical to B. superciliaris". Alexander Agassiz however considers $B$. mertensi to be a separate species from $B$. bougainvillei Lesson (according to Agassiz) but identical with what Brandt called $B$. bougainvillei. This is correct because $B$. bougainvillei Lesson is $B$. macloviana, a different species from $B$. superciliaris; thus $B$. mertensi, as well as the specimens determined as $B$. bougainvillei by other authors must be referred to $B$. superciliaris. Bigelow (1913) also was inclined to consider $B$. mertensi a synonym of $B$. bougainvillei auct.

\section{Bougainvillia trinema (von Lendenfeld)}

Margelis trinema von Lendenfeld 1884b, p. 918, pl. 41, fig. 13.

Bougainvillia trinema Mayer 1910, p. 171. tralia.

Type LOCALity - Sydney Harbour, New South Wales, Aus-

HYDROID - Unknown.

Medusa - Umbrella oval, two to three mm high. Oral tentacles end in three (?) small equal branches about one third as long as the shaft of the oral tentacle. Marginal tentacles bear three tentacles each. Endoderm of stomach and tentacle-bulbs dark yellow.

Distribution - Sydney Harbour. Not again recorded since the original description.

Discussion - According to Mayer this might be a young B. fulva but Kramp (1953, p. 310) thinks this is improbable even though young specimens of $B$. fulva with three tentacles per marginal bulbs were found by him. In Kramp's B. fulva the oral tentacles dichotomously branched two to three times each of them with at least 8 terminal branches. $B$. trinema must therefore be regarded as an insufficiently described species.

\section{Bougainvillia vagans (Thornely)}

Perigonimus vagans Thornely 1908, p. 81, pl. 9, fig. 1. fathms.

Type LOCALITY - Khor Shinab, Sudanese Red Sea, 10-12

HYdRoId - Colony, much branched, $38 \mathrm{~mm}$ high. Stems alternately branched, perisarc slightly corrugated. Polyps dimorphic, some small on short stalks, others larger on longer stalks. 
Hydranth fusiform with about 25 tentacles. Gonophores, borne on short stems close below the hydranths, containing one medusa each.

\section{Distribution - Sudanese Red Sea.}

Discussion - As Rees (1956a, p. 345) has pointed out, this species is referred provisionally to Bougainvillia, pending the rediscovery of the hydroid. The original description is insufficient. A doubtful species. See discussion of B. balei.

\section{Bougainvillia yoldiae-arcticae (Birula)}

Perigonimus yoldiae-arcticae Birula 1897, p. 86, pl. 10, fig. 3 .

Jäderholm 1909, p. 45, pl. 1, fig. 17.

TYPE LOCALITY - Kandalakscha on Joldia arctica, $24 \mathrm{~m}$.

HYDROID - Stems unbranched, up to $5 \mathrm{~mm}$ high, arising from creeping anastomosing stolons living on bivalve shells. Perisarc smooth or faintly wrinkled with distinct nodes at intervals and dilated to form pseudohydrothecae around the base of the hydranths. Hydranths fusiform, with distinct hypostome, with a whorl of 5-12 tentacles heavily armed with nematocysts.

GoNosome - Unknown. The colonies studied are sterile.

Distribution - An arctic species. Kandalakscha, Nordenskiöld's Sea; East Greenland.

DisCUSSION - Rees (1956a, p. 346) has studied material referred to this species as Perigonimus yoldiae-arcticae and refers it provisionally to the genus Bougainvillia as an insufficiently known species.

$$
\text { III — LIST OF SYNONYMS }
$$

Valid or probable name

Synonyms

$\begin{array}{cl}\text { Bougainvillia } & (?) \\ , " & \text { balei } \\ \text { bitentaculata } & \text { britannica }\end{array}$

$$
\begin{array}{cc}
\text { Hyppocrene } & \text { britannica } \\
\text { " } & \text { simplex } \\
\text { Medusa } & \text { duodecilia } \\
\text { Margelis ramosa } & \text { ramitella } \\
, & \text { nygonema } \\
, & \text { britannica } \\
, \quad & \text { bella }
\end{array}
$$

Thamnitis nigritella

Bougainvillia nigritella

dinema 
Valid or probable name

Bougainvillia britannica

Bougainvillia carolinensis

$\begin{array}{ll}" & \text { crassa } \\ , & \text { frondosa } \\ , & \text { fulva } \\ , & \text { glorietta } \\ , & \text { inaequalis } \\ , & \text { linearis } \\ \text {, } & \text { longicirrha } \\ & \text { macloviana }\end{array}$

$\begin{array}{ll} & \text { maniculata } \\ , & \begin{array}{l}\text { multitentaculata } \\ \text { meinertiae } \\ \text { multicilia } \\ \text { muscoides }\end{array} \\ , & \text { nanella } \\ \text { niobe } \\ \text { obscura } \\ \text { platygaster } \\ \text { principis } \\ , \quad \\ \\ \\ \end{array}$

?Bougainvillia robusta Bougainvillia superciliaris

$\begin{array}{ll}, & \text { trinema } \\ , & \text { vagans } \\ , & \text { yoldiae-arcticae }\end{array}$

\section{Synonyms}

$\begin{array}{cl}\text { Bougainvillia } & \text { flavida (in part) } \\ , & \text { xantha } \\ , & \text { bella } \\ " & \text { simplex } \\ & \text { charcoti } ?\end{array}$

Perigonimus linearis

Hippocrene carolinensis Margelis carolinensis

Cyanaea bougainvillii

Hippocrene macloviana Perigonimus maclovianus Margelis maniculata Lizzia maniculata

\section{Lizusa multicilia \\ Perigonimus muscoides Bougainvillia nordgaardi \\ Perigonimus nanellus}

Hippocrene platygaster Margelis principis Bougainvillia allmani Hippocrene aurea Lizusa prolifera Hippocrene pyramidata Margelis pyramidata Eudendrium ramosum Medusa ocilia (octocilia) Atractylis ramosa Lizusa octocilia Margelis ramosa autumnalis

Perigonimus muscus Bougainvillia fruticosa

$\begin{array}{ll} & \text { vanbenedeni }(=\text { benedeni) } \\ " & \text { muscus } \\ \text { flavida (medusa in part) } & \text { gibbsi }\end{array}$

?Perigonimus robustus Bougainvillia bougainvillei Hippocrene superciliaris Bougainvillia mertensi Margelis trinema paradoxa

Perigonimus yoldiae-arcticae 


\section{IV - ZOOGEOGRAPHY OF THE GENUS}

Twenty-nine different names are listed in the above revision of the genus Bougainvillia. Of nine of these only the hydroid is known; of thirteen only the medusae, some of these may belong to the hydroids mentioned above, but their metagenetic correlation is not yet known. Of only seven species both generations are known. The constant feature of the genus is its neritic character.

Of the nineteen listed names of medusae only sixteen may be considered good species and of these we will attempt to study the geographic distribution.

By plotting the horizontal distribution of these species, the picture that emerges is the great preponderance of Atlantic over Pacific and Indian Ocean species and the concentration of the better defined species in cold waters, either Antarctic or Arctic and boreal.

A single species has a wide latitudinal and longitudinal range of distribution, it is a temperate species, penetrating into the circumsubtropical, southern boreal and sub-antarctic (?New Zealand) regions. This is B. ramosa; it is morphologically simple and is known to have a great ecological adaptability and is widely spread; it probably comes near the basic type or ancestral form of the genus. It is not a tropical species, has clear preference for temperate waters and we may presume it was an inhabitant of the former Tethys Sea.

From the primitive simple form whose present day representative seems to be $B$. ramosa a northern group of species evolved which find their optimum in cold waters and have certain morphological features in common. Another group of species spread into the warm Atlantic waters and only very few species reached the Indo-Pacific region.

1. The temperate group of species includes small forms with radial or interradial gonads, a small number of bulbar tentacles and two of them have lost their ocelli. They are the following: B. ramosa, B. bitentaculata (Japan), B. frondosa (warm temperate western Atlantic), B. maniculata (Mediterranean), B. muscoides (Norway, ?west coast of North America), B. pyramidata (western coast of the British Isles).

2. The cold water group of species includes large medusae with a larger number of bulbar tentacles, either adradial or interradial gonads and a large number of branches of the oral tentacles. They are the following: B. britannica (boreal), B. superciliaris (arctic), B. principis (northern boreal), B. macloviana (Antarctic Ocean), B. multitentaculata (boreal Pacific). 
3. The warm-water group of species is characterized by the small size, medium number of bulbar tentacles, medium number of branches of the oral tentacles and frequent vegetative reproduction of the medusae by budding young ones from the stomach, stolons or the like. These species are: B. carolinensis (Atlantic Ocean, Woods Hole to Brazil, Gold Coast), B. fulva (tropical-subtropical Indo-Pacific), $B$. niobe (West Indies), $B$. platygaster (tropical Atlantic and eastern coast of Africa), B. prolifera (New South Wales).

Comparing the species of these three groups between themselves, it is evident that the warm water species are the most closely related to each other with the only exception of $B$. fulva which has probably been isolated over a longer period of time. The cold water species are the most closely defined and better differentiated.

By far the greatest number of species inhabits the Atlantic Ocean and speciation has evolved further among the Atlantic species belonging to the cold water group. The co-existence of several different species of one genus in the same geographic area indicates that the genus has long since inhabited that area and has had time to undergo divergent speciation by adapting itself to the different ecological niches. Accordingly these macrogeographically sympatric species are well differentiated and clearly defined. In the genus Bougainvillia these are predominantly Atlantic but have spread by means of the Arctic and Antarctic Oceans respectively to the North and South Pacific and to the Arctic Seas. One of them has occupied the whole Antarctic Ocean (B. macloviana).

There are only two species which are typically Pacific or Indo-Pacific; one, $B$. bitentaculata, is a close relative of the widely spread $B$. ramosa and the other is the warm water, abundant and widely distributed $B$. fulva. The latter having found little competition has spread into Indian Ocean and as far as the eastern Pacific where it evidently arrived after the emergence of the Panama isthmus in the Pliocene.

Except for the warm loving Indo-Pacific B. fulva, all the other warm water species are Atlantic and only one of them has been able to spread round the Cape of Good Hope, from the Atlantic towards the Indian Ocean, this being $B$. platygaster which is found also along the Zanzibar Coast.

Evidently this picture of the Zoogeography of the genus Bougainvillia will change with time when more will be known about the species considered at present to be doubtful and specially when the metagenetic correlation between the hydroids and medusae will be cleared. However, what is known of the morphological and geographical data agrees so nicely that we believe the overall picture to be correct. The preponderance of North Atlantic and North 


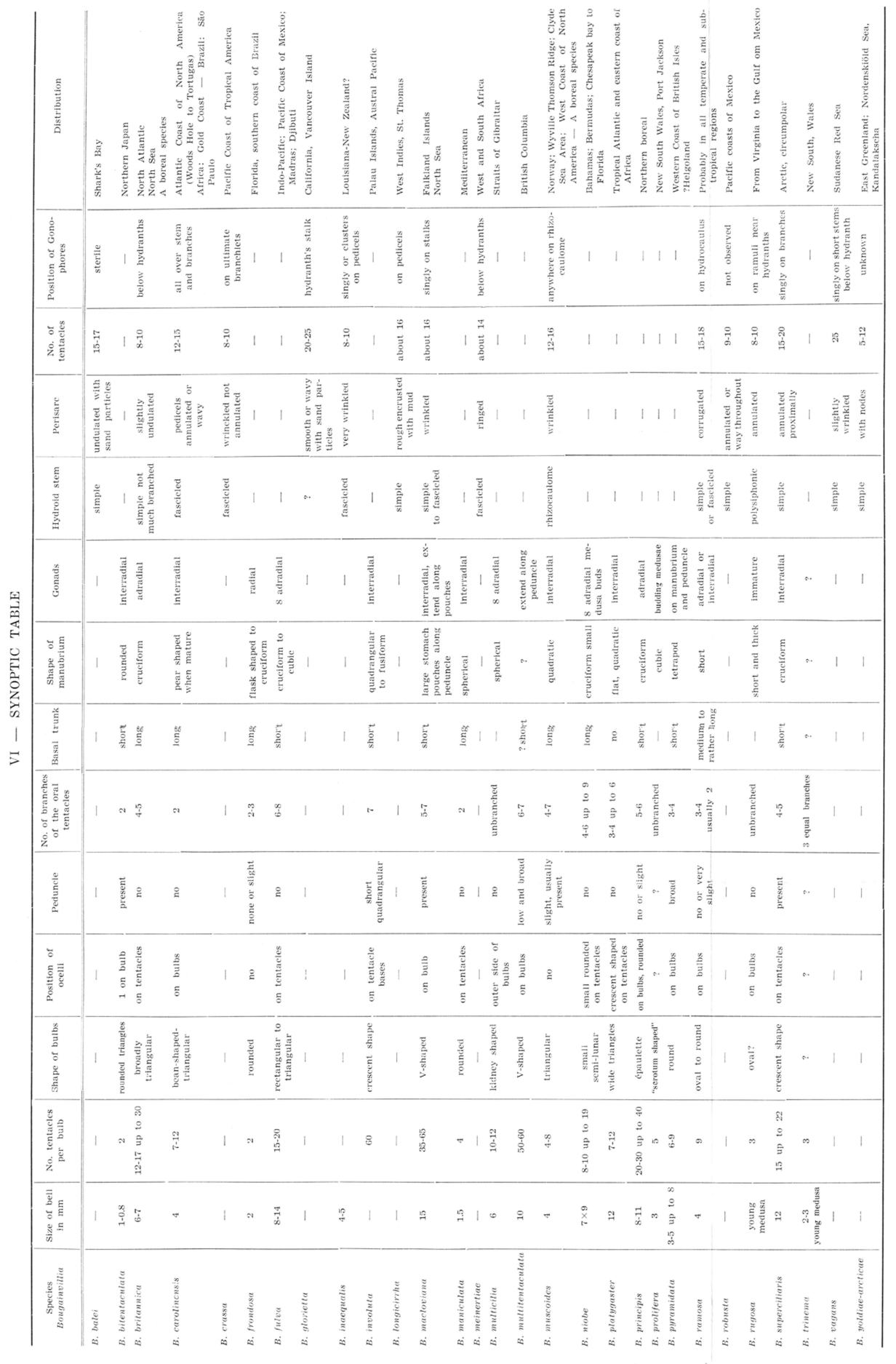


Sea species will probably be reduced when more is known about other regions. We are fully aware of the fact that, as Ekman puts it: "probably no oceanic region has been investigated more intensively than the boreal Atlantic region, the centre of which is represented by the North Sea".

\section{$\mathrm{V}$ - RESUMO}

Os autores fizeram uma revisão do gênero Bougainvillia, incluindo tôdas as espécies descritas sob êsse nome e tôdas aquelas realmente pertencentes a êsse gênero, anteriormente descritas sob outros nomes. De cada espécie é dada uma lista de sinônimos a mais completa possível, assim como uma descrição detalhada. As espécies válidas são reunidas numa tabela sinótica com os dados que foi possivel reunir para cada espécie.

Estabelecida a sinonímia na base dos caracteres morfológicos, foi estudada a zoogeografia do gênero. Tudo indica ser $B$. ramosa a forma simples primitiva da qual derivaram as demais espécies. Desta forma, ou de outra próxima a ela, teria derivado um grupo de espécies de águas temperadas com certas características morfológicas comuns a tôdas, e, afora uma que é do Japão, habitantes do Atlântico ou mares adjacentes.

Um segundo grupo de espécies teria evoluído em águas frias árticas ou boreais e antárticas, também com caracteres morfológicos em comum.

Por fim, um terceiro grupo de espécies teria evoluído em águas tropicais tanto do Atlântico como do Pacífico, apresentando, igualmente, caracteristicas morfológicas em comum.

Considerando o número de espécies e sua distribuição, o gênero Bougainvilia aparece como um gênero inicialmente atlântico, havendo apenas duas espécies distribuidas exclusivamente no Pacífico ou Indo-Pacífico.

\section{VII - REFERENCES}

Agassiz, A.

1865. North American Acalephae. Illustrated Catalogue of the $\mathrm{Mu}$ seum of Comparative Zoology, n. 2, p. 1-234, 360 text-figs.

Agassiz, A. \& Mayer, A. G.

1899. Acalephs from the Fiji Islands. Bull. Mus. Comp. Zool. Harvard, vol 32 , p. 157-189, pls. 1-17.

1902. Reports of the Scientific Results of the Expedition to the Tropical Pacific of the U.S. Fish Commission Steamer "Albatross" 1899-1900. III. Medusae. Mem. Mus. Comp. Zool. Harvard, vol. 26 , p. 139-176, pls. 11-14.

Agassiz, L.

1849. Contributions to the Natural History of the Acalephae of North America. Part. I. On the naked-eyed medusae of the shores of Massachussetts, in their perfect state of development. Mem. Amer. Acad. Arts Sci. Boston, vol. 4, p. 221-316, pls. 1-8.

1862. Contributions to the Natural History of the United States of America. vol. 4, 380p. pls. 20-34. Boston, Little, Brown \& Co.

AlDER, J.

1862. Supplement to a Catalogue of the Zoophytes of Northumberland and Durham. Trans. Tyneside Nat. Field Club, vol. 5, p. 225247, pls. 8-11. 
Allman, G. J.

1864. On the construction and limitation of genera among the $\mathrm{Hy}$ droida. Ann. Mag. Nat. Hist., ser. 3, vol. 13, p. 345-380.

1871-1872. A Monograph of the Gymnoblastic or Tubularian Hydroids. Ray Soc. Monograph, p. 1-450, pls. 1-23.

BABNIK, P.

1948. Hidromeduze iz srednjega in Južnega jadrana V Letih 1939 in 1940. Acta Adriatica, vol. 3, n. 9, p. 275-348, 4 tables.

Berezina, N. A.

1948. Check list of the Fauna and Flora of the Northern Seas of the U.S.S.R. Hydroidea. p. 47-65, pls. 14-17. Moscow.

BERrILl, N. J.

1949. Growth and Form in Gymnoblastic Hydroida. I. Polymorphic development in Bougainvillia and Aselomaris. J. Morph., vol. 84, p. $1-30$.

1950. Development and Medusa bud formation in the Hydromedusae. Quart. Rev. Biol., vol. 25, p. 292-316, figs. 1-10.

Bigelow, H. B.

1909a. Reports on the Scientific Results of the Expedition to the Eastern Tropical Pacific ... U.S. Fish Commission Steamer "Albatross" etc. XVI. The Medusae. Mem. Mus. Comp. Zool. Harvard, vol. 37, p. 1-243, pls. 1-48.

1909b. Coelenterates from Labrador and Newfoundland, etc. Proc. U.S. Nat. Mus., vol. 37, n. 1706, p. 301-320, pls. 30-32.

1913. Medusae and Siphonophorae collected by the U.S. Fisheries Steamer "Albatross", in the Northwestern Pacific, 1906. Proc. U.S. Nat. Mus., vol. 44, n. 1946, p. 1-119, pls. 1-6.

1918. Some Medusae and Siphonophorae from the Western Atlantic. Bull. Mus. Comp. Zool. Harvard, vol. 62, p. $365-442,8$ pls.

1919. Hydromedusae, Siphonophorae and Ctenophores of the "Albatross" Philippine Expedition. Bull. U.S. Nat. Mus., vol. 1, n. 100 , p. $279-362$, pls. $39-43$.

1938. Plankton of the Bermuda Oceanographic Expeditions. VIII. Medusae taken during the years 1929 and 1930. Zoologica, N.Y., vol. 23, p. 99-189.

Birula, A.

1897. Recherches sur la biologie et la zoogéographie principalement des mers dans les Golfes du Jenissei et de l'Obi. Ann. Mus. Zool. Acad. Sci., St. Pétersburg, vol. 2, p. 78-116.

BONNEVIE, K.

1898. Zur Systematik der Hydroiden. Zeits. Wiss. Zool., vol. 63, p. 465-495, pls. 25-28.

BRANDT, J. T.

1838. Ausführliche Beschreibung der von C. H. Mertens auf Seiner Weltumsegelung beobachteten Schirmquallen ... Mém. Acad. Sci. St. Pétersbourg, ser. 6, vol. 4, Sci. Math. et Nat., vol. 2, p. 237-411, pls. 1-31.

Briggs, E. A.

1931. Notes on Australian Athecate Hydroids. Rec. Austr. Mus. Sydney, vol. 18 , p. 279-282. 
BRINK, R.

1924. Notes concerning the Variability and the Action of Environmental Influences etc. ... Proc. Sci. K. Acad. Wet., Amsterdam, vol. 27, p. 726-733.

1925. Beiträge zur Herstellung einer rationellen Hydroiden-systematik. I. Über einige lokale Formen der Hydroiden-art Bougainvillia ramosa (v. Ben.) Lesson. Tijdschr. Ned. Dierk. Ver. Leiden, ser. 2, vol. 19, p. 126-166, pl. 6.

Broch, H.

1933. Zur Kenntnis des Adriatischen Hydroidenfauna von Split. Norske Vidensk.-Akad. Oslo. I. Math. Naturw. Kl., vol. 4, p. 1-115.

Browne, E. T.

1896. The Medusae of Valencia Harbour, County Kerry. Irish Naturalist, vol. 5, p. 179-181.

1900. The Fauna and Flora of Valencia Harbour on the West Coast of Ireland. I. The Pelagic Fauna (1895-1898); II. The Medusae (1895-1898). Proc. Roy. Irish Acad., ser. 3, vol. 5, p. 667-693; 694-736, pls. 20-21.

1902. Preliminary Report of the Hydromedusae from the Falkland Islands. Ann. Mag. Nat. Hist., ser. 7, vol. 9, p. 272-284.

1903. Report on some Medusae from Norway and Spitsbergen. Bergen Mus. Aarb., n. 4, p. 1-36, pls. 1-5.

Browne, E. T. \& Kramp, P. L.

1939. Hydromedusae from the Falkland Islands. Discovery Rep., vol. 18 , p. $265-322$, pls. $14-19$.

Clarke, S. T.

1882. New and interesting Hydroids from Chesapeake Bay. Mem.

Boston Soc. Nat. Hist., vol. 3, p. 135-142, pls. 7-9.

Deevey, E. S.

1950. Hydroids from Lousiana and Texas, with remarks on the Pleistocene biogeography of the western Gulf of Mexico. Ecology, vol. 31, p. 334-367. Lancaster, $\mathrm{Pa}$.

1954. Hydroids of the Gulf of Mexico. Fish and Wildlife Service. Fishery Bull., n. 89, p. 267-272.

DUNBAR, M. J.

1942. Marine Macroplankton from the Canadian Eastern Arctic. II. Medusae etc. ... Canad. J. Res. Ottawa, 20D, p. 71-77.

EDWARDS, C.

1958. Hydromedusae new to the British List from the Firth of Clyde. Nature, vol. 182 , n. 4649 , p. 1564-1565.

Foerster, R. E.

1923. The Hydromedusae of the West Coast of North America, with special reference to those of the Vancouver Island Region. Contr. Canad. Biol., n.s., vol. 1, p. 219-277, pls. 1-5.

Forbes, E.

1841. Contributions to British Actinology. Ann. Mag. Nat. Hist., vol. 7 , p. $81-85$, pl. 1 .

1848. A Monograph of the British Naked-Eyed Medusae: with figures of all species. Ray Soc. Monograph, p. 1-104, pls. 1-13.

Forbes, E. \& Goodsir, J.

1851. On some remarkable marine invertebrates new to the British Seas. Trans. Roy. Soc. Edinb., vol. 20, p. 307-315, pls. 9-10. 
Fraser, C. M.

1937. Hydroids of the Pacific Coast of Canada and the United States. 208 p. 44 pls. Toronto.

1938. Hydroids of the 1934 Allan Hancock Pacific Expedition. Allan Hancock Pac. Exp., vol. 4, n. 1, p. 1-105, pls. 1-15.

1944. Hydroids of the Atlantic Coast of North America. 451p. 94 pls. Toronto, Univ. Toronto Press.

Gould, A. A.

1841. Report on the Invertebrata of Massachussetts, comprising the Mollusca, Crustacea, Annelida and Radiata. 375p. 15 pls. Cambridge, Mass.

HAECKEL, E.

1864. Beschreibung neuer Craspedoter Medusen aus dem Golfe von Nizza. Zeits. Med. u. Naturw. Jena, vol. 1, p. 325-342.

1877. Prodromus des System der Medusen. (Unpublished).

1879. Das System der Medusen. 672 pp. 40 pls. Jena.

Hallez, P.

1905. Bougainvillia fruticosa Allman est le faciés d'eau agitée de Bougainvillia ramosa van Beneden. C. R. Acad. Sci. Paris, 13 fév. $140 \mathrm{a}$, p. $457-459$.

HargitT, C. W.

1901. Synopsis of North American Invertebrates. XIV. The Hydromedusae. Part II. Amer. Nat., vol. 35, p. 379-395.

1904. The Medusae of the Woods Hole Region. Bull. U.S. Bureau Fisheries, vol. 24, p. 21-79, pls. 1-7.

Hartlaub, C.

1897. Die Hydromedusen Helgolands. Wiss. Meeresunt. (N.F.), vol. 2 , fasc. $1, \mathrm{X}$, p. $449-512$, pls. $14-23$.

1909a. Über einige von Ch. Gravier in Djibuti gesammelte Medusen. Zool. Jahrb. Syst., vol. 27, p. 447-476, pls. 19-23.

1909b. Méduses. Croisières Océanographiques accomplies à bord de la Belgica dans la Mer do Grönland, 1909, p. 1-18, pls. 76-77.

1911. Nordisches Plankton, fasc. 15, XII. Craspedote Medusen. Part 1, p. 1-479.

HINCKS, T.

1868. A History of British Hydroid Zoophytes. 2 vol.

Hodge, G.

1861. Contribution to the Marine Zoology of Seaham Harbour. Trans. Tynes. Field Club., vol. 5, p. 78-82, pl. 2, figs. 10-15.

HumMelinck, P. W.

1936. Hydropoliepen. Flora en Fauna der Zuiderzee Helder. Suppl. p. 41-64.

JÄDERHOLM, E.

1909. Northern and Arctic Invertebrates in the Collection of the Swedish State Museum. IV. Hydroiden. K. Svenska Vetensk.Akad. Handl., vol. 45, p. 1-124, pls. 1-12.

1922. Hydroids from West and South Africa. Meddel. Göteborg Vet. Handl. (F. 4), vol. 26, p. 3-7.

KRAMP, P. L.

1926. Medusae. Part II. Anthomedusae. Danish Ingolf Exp., vol. 5, p. 1-102, pls. 1-2, 18 maps. 
KRAMP, P. L.

1927. The Hydromedusae of the Danish Waters. Mém. Acad. Sc. Lettres Danemark. Sect. Sci., ser. 8, vol. 12, p. 1-291, 2 textfigs., 24 text-charts.

1928. Papers from Dr. Th. Mortensen's Pacific Expedition 1914-1916. 43. Hydromedusae. Vidensk. Medd. naturh.-Foren. Kjobenhavn, vol. 85 , p. $27-64$, figs. $1-30$.

1937. Polypdyr (Coelenterata). II Gopler. Danmark's Fauna, vol. 43 , p. $1-223$.

1939. Medusae, Siphonophora and Ctenophora. Zool. Iceland, vol. 2, pt. 5b, p. 1-37.

1942. Godthaab Expedition 1928, Medusae. Medd. Gronl., vol. 81, p. 1-168.

1948a. Trachymedusae and Narcomedusae from the "Michael Sars" North Atlantic Deep-Sea Expedition... Rep. Sci. Res. "Michael Sars" 1910, vol. 5, p. 1-23, 1 pl.

1948b. Medusae collected by the Swedish Antarctic Expedition 19011903. Zool. Res. Swedish Ant. Exp. 1901-1903, vol. 4, pl. 1-16.

1952. Medusae collected by the Lund University Chile Expedition 1948-49. Rep. Lund Univ. Chile Exp. Lunds. Univer. Arssk. N.F. vol. 47 , n. 7 , p. 3-19.

1953. Hydromedusae. Sci. Rep. Great Barrier Reef Exp., vol. 6, p. 259-322, pls. $1-2$.

1955. The Medusae of the Tropical West Coast of Africa. Atlantide Rep. n. 3. Scient. Res. Danish Exp. Trop. West Africa 1945-46, p. 239-324, pls. 1-3.

1957. Hydromedusae from the Discovery Collections. Discovery Rep., vol. 29 , p. 1-128, pls. 1-7.

1959. The Hydromedusae of the Atlantic Ocean and adjacent waters. Dana Report n. 46, 283p. 2 pls.

KRAMP, P. L. \& DAMAS, D.

1925. Les Méduses de la Norvège. Introduction et partie spéciale. I. Vidensk. Medd. naturh. Foren. Kobenhavn., vol. 80, p. 217 323 , pl. 35 .

KÜNNE, C.

1933. Zur Kenntnis der Anthomeduse Bougainvillia macloviana Lesson. Zool. Anz. Leipzig, vol. 101, p. 249-254, fig. 1.

1937. Über als "Fremdlige" zu bezeichnende Grossplanktonten in der Ostee. Rapp. Proc. Verb. Réun., Cons. Int. Expl. Mer, vol. 2, p. 1-7.

Le Danois, E.

1913. Coelentérés du plankton recueilli pendant la croisière océanographique du yacht "Pourquoi Pas?" ... Bull. Soc. Zool. France, vol. 38 , p. 1-34, figs. 1-21.

LESSON, R. P.

1830. Voyage autour du monde sur la corvette "La Coquille" ... Zool., 2 vols. Atlas in folio. Paris.

1936. Mémoire sur la famille des Béroïdes. Ann. Sci. Nat. Paris, ser. 2 , vol. 5 , p. 235-266.

1843. Histoire Naturelle des Hydroides Acalèphes. 596 p. Paris.

LING, S.

1937. Studies on the Chinese Hydrozoa. I. On some Hydromedusae of the Chekiang Coast. Peking Nat. Hist. Bull., vol. 11, p. 351-365. 
LINKO, A.

1904. Zoologische Studien in Barents-Meere. Auf Grund der Untersuchungen der Wissenchaftlichen Murman-Expedition. Zool. Anz., vol. 28, p. 210-220.

MAAS, O.

1905. Die Craspedoten Medusen der Siboga-Expedition. Siboga-Exp., X. 85p. pls. 1-14.

1906. Méduses d'Amboine. Rev. Suisse Zool., vol. 14, p. 81-107, pls. $2-3$.

MAYer, A. G.

1894. Cruise of the Steam Yacht "Wild Duck" in the Bahamas ... III. An account of some medusae obtained in the Bahamas. Bull. Mus. Comp. Zool. Harvard, vol. 25, p. 235-241, pls. 1-3.

1900a. Some Medusae from the Tortugas, Florida. Bull. Mus. Comp. Zool. Harvard, vol. 37, p. 13-82, pls. 1-44.

1900b. Descriptions of new and little-known medusae from the Western Atlantic. Bull. Mus. Comp. Zool. Harvard, vol. 37, p. 1-9. pls. 1-6.

1904. Medusae of the Bahamas. Mem. Nat. Sci. Mus. Brooklyn Inst. Arts Sci., vol. 1, p. 1-33, pls. 1-7.

1910. Medusae of the World, Hydromedusae, vol. 1, p. 1-230, pls. 1-29. Washington.

MacGinitie, G. E.

1955. Distribution and ecology of the marine invertebrates of Point Barrow, Alaska. Smiths. Misc. Coll., vol. 128, n. 9, p. iv +201.

MCCRADY, J.

1858. Gymnophthalmata of Charleston Harbour. Proc. Elliot Soc Nat Hist. Charleston, South Carolina, vol. 1, p. 103-294, pls. 8-14.

MereschKowsky, C.

1879. On an anomaly among the Hydromedusae, and on their mode of nutrition by means of the ectoderm. Ann. Mag. Nat. Hist., ser. 5 , vol. 3 , p. $177-181$, pl. 20.

NAIR, K. K. 1951 \& 1954. Medusae of the Travancore Coast. Part I. Systematic. Bull.
Centr. Res. Inst. Travancore, 2c(1), p. 47-75, 1 pl. Part II. Seasonal distribution. Ibid. 3c(1), p. 31-68.

NaUmov, D. V.

1956. Medusae from the seas of the far-east of the U.S.S.R. Zool. Inst. Acad. Sc. U.R.S.S., fasc. 6, p. 36-41.

Nepri, V. \& Stiasny, G.

1913. Die Hydromedusen des Golfes von Triest. Arb. Zool. Inst. Wien und Zool. Stat. Triest, vol. 20, p. 23-90, pls. 1-4.

Nutting, C. C.

1901. The Hydroids of the Woods Hole Region. Bull. U.S. Fish. Comm. for 1899, vol. 19, p. 325-386.

Perrier, R.

1936. La Faune de la France. 1A, p. 8-64, 118 pls. Paris. 
PICARD, J.

1958. Origines et affinités de la faune d'hydropolypes (gymnoblastes et calyptoblastes) et d'hydroméduses de la Mediterranée. Rapp. Proc. Verb. Réun., Commiss. Explor. Medit., n.s., vol. 14, p. 187-199.

Pictet, C.

1893. Etude sur les Hydraires de la Baie d'Amboine. Rev. Suisse Zool., vol. 1, p. 1-64, pl. 1-3.

Ralph, P. M.

1953. A Guide to the Athecate (Gymnoblastic) Hydroids and Medusae of New Zealand. Tuatara, vol. 5, p. 59-75.

REES, W. J.

1938. Observations on British and Norwegian Hydroids and their Medusae. J. Mar. Biol. Ass. U.K., vol. 23, p. 1-42.

1956a. A revision of the Hydroid genus Perigonimus M. Sars, 1846. Bull. Brit. Mus. (Nat. Hist.), vol. 3, p. 337-350.

1956b. A Revision of some northern Gymnoblastic Hydroids in the Zoological Museum, Oslo. Nytt. Mag. Zool. Oslo, vol. 4, p. 109-120.

Romanes, G. J.

1876. An account of some new species, varieties and monstruous forms of medusae. J. Linn. Soc. London, Zool., vol. 12, p. 524-531.

1877. An account of some new species, varieties and monstruous forms of medusae. II. J. Linn. Soc. London, Zool., vol. 13, p. 190-194, pls. 15-16.

Russell, F. S.

1938. The Plymouth off-shore Medusa Fauna. J. Mar. Biol. Ass. U.K., vol. 22 , p. 411-439.

1953. The Medusae of the British Isles. xiii +530 p., 35 pls. Cambridge.

SARS, M.

1846. Fauna Littoralis Norvegiae. Fasc. 1, p. 1-94, pls. 1-10.

SPAGNOLINI, A.

1871. Catalogo degli Acalefi Discofori del Golfo di Napoli. Atti Soc. Ital. Sc. Nat. Milano, vol. 14, p. 144-223.

Stechow, E.

1909. Hydroidpolypen der japanischen Ostküsten. Akad. Wissen. Bayer. Math.-phys. Kl., vol. 6, Suppl. 1, p. 1-109, 7 pls.

1914. Zur Kenntnis neuer oder seltener Hydroidpolypen, meist Campanulariiden, aus Amerika und Norwegen. Zool. Anz., vol. 45, p. 120-136.

1919. Zur Kenntnis der Hydroidenfauna des Mittelmeeres, Amerika und anderer Gebiete. II Teil. Zool. Jahrb. Syst., vol. 42, p. 1-172.

1924. Diagnosen neuer Hydroiden aus Australien. Zool. Anz., vol. 59, p. 57-69.

1925. Hydroiden von West- und Südwestaustralien ... Zool. Jahrb. Syst., vol. 50, p. 191-269. 
Steenstrup, J. J. S.

1850. In Lütken. Nogle Bemaerkninger om Medusernes systematiske Inddeling, navnling med Hensyn til Forbes's History of British Naked-Eyed medusae. Vidensk. Med. Naturh. Foren. Kbn., 1850, p. 15-35.

THIEL, M. E.

1938. Die Leptolinae der "Meteor" Expedition in Systematischer Betrachtung. I. Anthomedusae. II. Leptomedusae. Zool. Anz., vol. 121 , p. $289-303$; p. 322-336.

THORNELY, L. R.

1908. Reports on the marine biology of the Sudanese Red Sea. X. Hydroida collected by Mr. Cyril Crossland etc. ... J. Linn. Soc. London, Zool., vol. 31, p. 80-85, pl. 9, fig. 1.

TORREY, H. B

1904. The Hydroida of the San Diego Region. Univ. California Publ. Zool., vol. 2, p. 1-43.

UCHIDA, T.

1925. The Hydroida from Northern Japan. Jap. J. Zool. Tokyo, vol. 1, p. $77-100$.

1938. Medusae in the vicinity of the Amakusa Marine Biologicai Station. Bull. Biogeog. Soc. Tokyo, vol. 8, p. 143-149.

1947. Some Medusae from the Central Pacific. J. Fac. Sci. Hokkaido Univ. Zool., vol. 9, p. 297-319.

VAN BENEDEN, P. J.

1844. Recherches sur l'Embryogénie des Tubulaires, et l'Histoire Naturelle des différents genres de cette famille qui habitent la côte d'Ostende. Mém. Acad. Roy. Belgique, vol. 17, p. 1-72, pls. 1-6.

VANHÖFFEN, E.

1909. Die Hydroiden des Deutschen Südpolar-Expedition 1901-1903. Deuts. Südp.-Exp., vol. 11, Zool., p. 271-340.

1912. Die Craspedoten Medusen des Deutschen Südpolar-Expedition 1901-1903. Deuts. Südp. Exp., vol. 12, Zool., p. 353-395, pls. 24-25.

VANNuCCI, M.

1951. Hydrozoa e Scyphozoa existentes no Instituto Paulista de Oceanografia. Bol. Inst. Paul. Ocean., vol. 2, p. 69-100, pls. 1-4.

1957. On Brazilian Hydromedusae and their distribution in relation to different water masses. Bol. Inst. Ocean., vol. 8, p. 23-109.

VERVOORT, W.

1942. Northern Hydroida in the Collections of the Rijksmuseum van Naturlijke Historie and the Zoological Museum at Amsterdam, with notes on their distribution. Zool. Meded. Leiden, vol. 23, p. 275-312.

1946a. Hydrozoa. Fauna van Nederland. Leiden. vol. 14, p. 1-336. 1946b. Hydroiden uit den Waddenzee. Arch. Néerl. Zool., vol. 7, p. 334-352.

VON LENDENFELD, R.

1884a. The Australian Hydromedusae. Part V. Conclusion. Proc. Linn. Soc. N.S. Wales, vol. 9, p. 581-634, pls. 20-29.

1884b. Addenda to the Australian Hydromedusae. Proc. Linn. Soc. N.S. Wales, vol. 9, p. 908-924, pls. 40-43. 